\title{
Task 3.8 - Pressurized Fluidized-Bed Combustion
}

\author{
Topical Report \\ March 1995
}

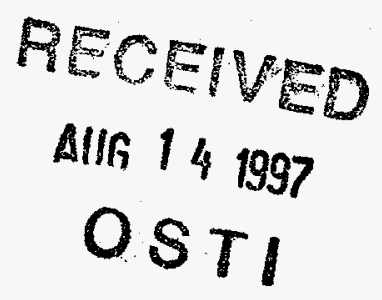

Work Performed Under Contract No.: DE-FC21-93MC30097

For

U.S. Department of Energy

Office of Fossil Energy

Federal Energy Technology Center

Morgantown Site

P.O. Box 880

Morgantown, West Virginia 26507-0880

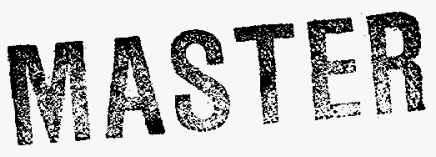

$$
\text { DSTAREUTION OF THIS DOCUMENT IS UNATED }
$$

Energy \& Environmental Research Center

University of North Dakota

P. O. Box 9018

Grand Forks, North Dakota 58202-9018 


\section{Disclaimer}

This report was prepared as an account of work sponsored by an agency of the United States Government. Neither the United States Government nor any agency thereof, nor any of their employees, makes any warranty, express or implied, or assumes any legal liability or responsibility for the accuracy, completeness, or usefulness of any information, apparatus, product, or process disclosed, or represents that its use would not infringe privately owned rights. Reference herein to any specific commercial product, process, or service by trade name, trademark, manufacturer, or otherwise does not necessarily constitute or imply its endorsement, recommendation, or favoring by the United States Government or any agency thereof. The views and opinions of authors expressed herein do not necessarily state or reflect those of the United States Government or any agency thereof. 


\section{DISCLAIMER}

Portions of this document may be illegible electronic image products. Images are produced from the best available original document. 


\section{DISCLAIMER}

This report was prepared as an account of work sponsored by an agency of the United States Government. Neither the United States Government, nor any agency thereof, nor any of their employees makes any warranty, express or implied, or assumes any legal liability or responsibility for the accuracy, completeness, or usefulness of any information, apparatus, product, or process disclosed or represents that its use would not infringe privately owned rights. Reference herein to any specific commercial product, process, or service by trade name, trademark, manufacturer, or otherwise does not necessarily constitute or imply its endorsement, recommendation, or favoring by the United States Government or any agency thereof. The views and opinions of authors expressed herein do not necessarily state or reflect those of the United States Government or any agency thereof.

\section{ACKNOWLEDGMENT}

This final topical report was prepared with the support of the U.S. Department of Energy (DOE), Morgantown Energy Technology Center, Cooperative Agreement No. DE-FC2193MC30097. However, any opinions, findings, conclusions, or recommendations expressed herein are those of the author(s) and do not necessarily reflect the views of the DOE.

\section{EERC DISCLAIMER}

LEGAL NOTICE This research report was prepared by the Energy \& Environmental Research Center (EERC), an agency of the University of North Dakota, as an account of work sponsored by Morgantown Energy Technology Center. Because of the research nature of the work performed, neither the EERC nor any of its employees makes any warranty, express or implied, or assumes any legal liability or responsibility for the accuracy, completeness, or usefulness of any information, apparatus, product, or process disclosed, or represents that its use would not infringe privately owned rights. Reference herein to any specific commercial product, process, or service by trade name, trademark, manufacturer, or otherwise does not necessarily constitute or imply its endorsement or recommendation by the EERC. 


\section{TABLE OF CONTENTS}

LIST OF FIGURES $\ldots \ldots \ldots \ldots \ldots \ldots \ldots \ldots \ldots \ldots \ldots \ldots \ldots \ldots \ldots \ldots$

LIST OF TABLES $\ldots \ldots \ldots \ldots \ldots \ldots \ldots \ldots \ldots \ldots \ldots \ldots \ldots \ldots \ldots \ldots$ iii

1.0 INTRODUCTION $\ldots \ldots \ldots \ldots \ldots \ldots \ldots \ldots \ldots \ldots \ldots \ldots \ldots \ldots \ldots \ldots \ldots$

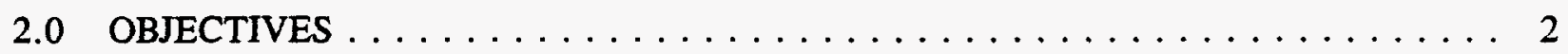

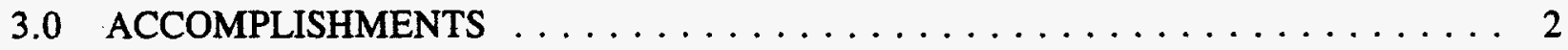

3.1 Description of Pressurized Fluidized-Bed Reactor $\ldots \ldots \ldots \ldots \ldots \ldots \ldots 2$

3.2 Alkali-Sampling Probe Description $\ldots \ldots \ldots \ldots \ldots \ldots \ldots \ldots \ldots$

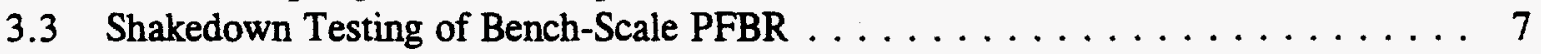

3.4 Results from Alkali Sampling $\ldots \ldots \ldots \ldots \ldots \ldots \ldots \ldots \ldots \ldots \ldots \ldots \ldots$

3.5 Results from Sulfur Sorbent Performance Tests $\ldots \ldots \ldots \ldots \ldots \ldots \ldots 14$

3.6 Results from Refuse-Derived Fuel and Lignite Combustion Tests . . . . . . . . 17

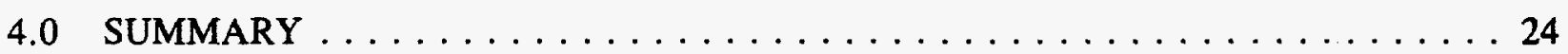

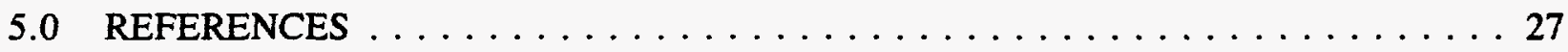




\section{LIST OF FIGURES}

1 Maximum allowable reactor working pressure over a range of temperatures $\ldots \ldots \ldots$

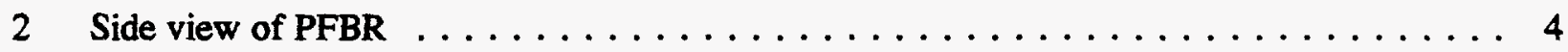

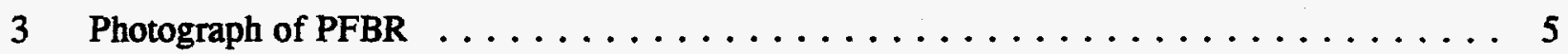

4 Photograph of the PFBR with heaters in place $\ldots \ldots \ldots \ldots \ldots$

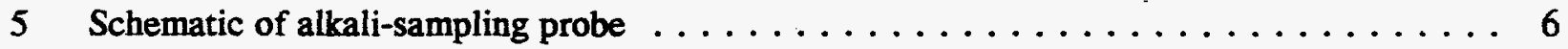

6 Temperature distributions for dry Knife River, Knife River slurry, and Little Tonzona slurry $\ldots \ldots \ldots \ldots \ldots \ldots \ldots$

7 Flue gas emissions over time for Knife River slurry $\ldots \ldots \ldots \ldots \ldots \ldots$

8 Comparison of flue gas emissions for three tests $\ldots \ldots \ldots \ldots \ldots \ldots$

9 Sulfur capture in the PFBR as a function of operating conditions $\ldots \ldots \ldots \ldots$

$10 \mathrm{NO}_{x}$ emissions from the PFBR as a function of operating conditions $\ldots \ldots \ldots$

$11 \mathrm{~N}_{2} \mathrm{O}$ emissions from the PFBR as a function of operating conditions $\ldots \ldots \ldots$

12 PFBR temperature distribution with various fuels $\ldots \ldots \ldots \ldots \ldots \ldots \ldots$

13 Comparison of $\mathrm{SO}_{2}$ emission and sulfur retention for each fuel type $\ldots \ldots \ldots \ldots$ 


\section{LIST OF TABLES}

1 Moisture-Free Fuel Analyses $\ldots \ldots \ldots \ldots \ldots \ldots \ldots \ldots$

2 Summary of Process Data $\ldots \ldots \ldots \ldots \ldots \ldots \ldots \ldots$

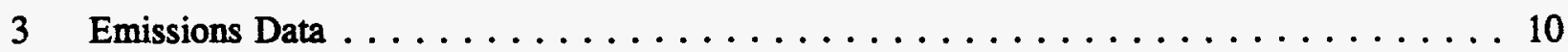

4 Proximate, Ultimate and XRF Analyses of Blacksville Bituminous, Beulah Lignite, and Plum Run Dolomite $\ldots \ldots \ldots \ldots \ldots \ldots$

5 Operating Conditions and Gas-Phase Species Composition

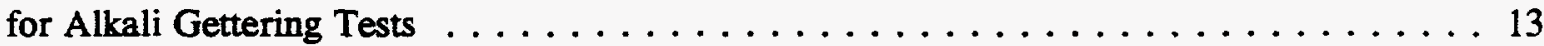

6 XRF Analysis of Filter Material Collected from Alkali-Sampling Probe

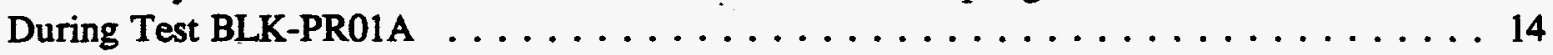

7 Test Matrix for Sulfur Sorbent Characterization $\ldots \ldots \ldots \ldots \ldots \ldots$

8 Operating Data and Emissions from Sulfur Sorbent Characterization Tests $\ldots \ldots \ldots$

9 Moisture, Proximate, Ultimate, Sulfur Forms, Heating Value, Ash Fusion, and Ash Analyses for Fuel Samples . . . . . . . . . . . . . . . . . 19

10 Average Operating Conditions from PFB Combustion Tests with Selected Fuels . . . . . . 20

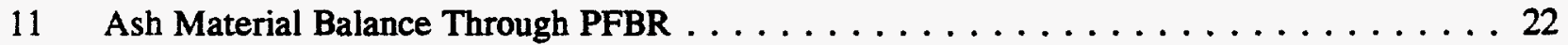

12 XRF and XRD Analyses of PFBR Lignite Fuel Ash (high-temperature ash, \% of ash) . . . 22

13 XRF and XRD Analyses of PFBR RDF Ash (high-temperature ash, \% of ash) . . . . . 23

14 XRF and XRD Analyses of PFBR RDF-Lignite Fuel Ash (high-temperature ash, \% of ash)

15 Results from TCLP Tests for RCRA Metals on Selected Combustion Products Derived from All Three Slurry Fuels $\ldots \ldots \ldots \ldots \ldots \ldots$ 


\section{TASK 3.8 PRESSURIZED FLUIDIZED-BED COMBUSTION}

\subsection{INTRODUCTION}

One of the overall goals of the U.S. Department of Energy is the development of the technology necessary to provide for a secure, reliable, affordable, and environmentally sound source of energy. A secure energy source is important to ensure economic stability and growth in the next century as well as to reduce current and minimize future environmental impact associated with power generation in the United States and the world as a whole. The continued and potentially expanded use of abundant coal reserves is one key to a secure and affordable source of energy in the United States.

Throughout the world, coal will play an expanded role in the production of the affordable energy necessary to meet the demands of economic development and growth. The development of more efficient and environmentally sound technology in the United States may present export market opportunities throughout the world; specific examples include East Central Europe and the Pacific Rim. In East Central Europe, where substantial coal utilization has occurred for decades, an urgent need exists for commercial emission control technology as well as for current clean coal technology. The lack of emission control technology in East Central Europe is exacting a high price in terms of human health and long-term environmental damage. In contrast, the Pacific Rim has only recently begun to expand the use of coal to meet energy demands created by economic growth. Therefore, the need in that region is for commercial and developing technologies to allow new coal-fired plants to meet current and future energy demands in an environmentally sound manner.

For coal to play a key role in the U.S. energy mix, it will be necessary to develop and commercialize technologies capable of producing electricity at significantly higher overall system efficiencies than the 30\%-35\% levels currently observed in conventional coal-fired systems. Also, the production of liquid and gaseous fuels from coal will be required to effectively meet the broad spectrum of future energy needs. To achieve overall system efficiencies of $40 \%-60 \%$ in an environmentally acceptable manner, development and demonstration of advanced secondgeneration utilization and conversion technology will be paramount. Examples include 1) advanced pulverized coal-fired combustion systems; 2) high-temperature heat exchangers for indirect firing of gas turbines; 3) pressurized combustion in staged, entrained, slagging, and fluidized-bed modes; and 4) integrated gasification and direct gas-fired turbines.

A number of barrier issues exist that are not unique to individual technologies but are in some manner common to all advanced power system processes for both oxidizing and reducing environments. Examples include material issues, specifically ceramic and refractory components, and operational issues unique to high-temperature pressurized systems. The focus of the current work on pressurized fluidized-bed combustion (PFBC) is the development of sorbents for in-bed alkali control. 


\subsection{OBJECTIVES}

The goal of the PFBC activity is to generate fundamental process information that will further the development of an economical and environmentally acceptable second-generation PFBC. The immediate objectives focus on generic issues, including the performance of sulfur sorbents, fate of alkali, and the Resource Conservation and Recovery Act (RCRA) heavy metals in PFBC. A great deal of PFBC performance relates to the chemistry of the bed and the contact between gas and solids that occurs during combustion. These factors can be studied in a suitably designed bench-scale reactor. The present studies are focusing on the emission control strategies applied in the bed, rather than in hot-gas cleaning. Emission components include alkali and heavy metals in addition to $\mathrm{SO}_{2}, \mathrm{NO}_{x}, \mathrm{~N}_{2} \mathrm{O}$, and $\mathrm{CO}$.

\subsection{ACCOMPLISHMENTS}

\subsection{Description of Pressurized Fluidized-Bed Reactor}

A pressurized fluidized-bed reactor (PFBR) has been constructed at the Energy \& Environmental Research Center (EERC) to simulate the bed chemistry, ash interactions, and emissions from a PFB under closely controlled conditions. This reactor is used for sorbent characterization, testing of gaseous emissions, including trace elements, and agglomeration and hot-gas cleanup testing in a cost-effective manner over a wide range of operational conditions. The 55-in.-tall reactor is constructed of 3-in. Schedule 80 pipe and is externally heated with three ceramic heaters. A hot cyclone collects the ash and bed material that is carried out of the reactor. The preheated fluidizing gas can be either air or a mixture of air and nitrogen; in addition, one additional gas such as carbon dioxide, carbon monoxide, sulfur dioxide, or a nitrogen oxide can be added to result in a fuel gas similar to that generated in a full-scale fluidized-bed combustor. Preheated gas at temperatures of up to $1400^{\circ} \mathrm{F}$ and pressures of up to $200 \mathrm{psig}$ are supplied at the bottom of the reactor through a 1 -in. Schedule 40 pipe. The fluidizing gas is supplied at sufficiently high velocities to prevent the sized bed material from dropping out during operation. Figure 1 shows the maximum allowable working pressure of the reactor at various temperatures.

The fluidizing gas enters the 3 -in. Schedule 80 main section of the reactor through a conical transition. This conical section was designed without a distributor plate to allow quick removal and quenching of the bed material after completion of a test. Bed material can be sampled or collected using a lock hopper system located at the bottom of the reactor. A sight port at the top of the reactor is fitted with a color video camera for on-line observation of the bed during either highpressure or atmospheric operation. A recorder may be added to the camera at a later date. Figure 2 is a side-view schematic of the reactor and cyclone. Figure 3 is a photograph of the actual reactor vessel, cyclone, air preheater, reactor collection pot and fuel feed hopper. Figure 4 is a photograph of the final system after the external heaters and other auxiliaries have been installed.

Temperatures in the reactor are measured with eleven Type $\mathrm{K}$ thermocouples: These are located at $0.25,1.75,3.5,5,7,9,11,15,23,31$, and 43.25 inches above the conical transition section. Thermocouples are also located at the gas inlet, the cyclone exit, and the pressure letdown valve inlet. A sampling port is located downstream of the pressure letdown valve. 


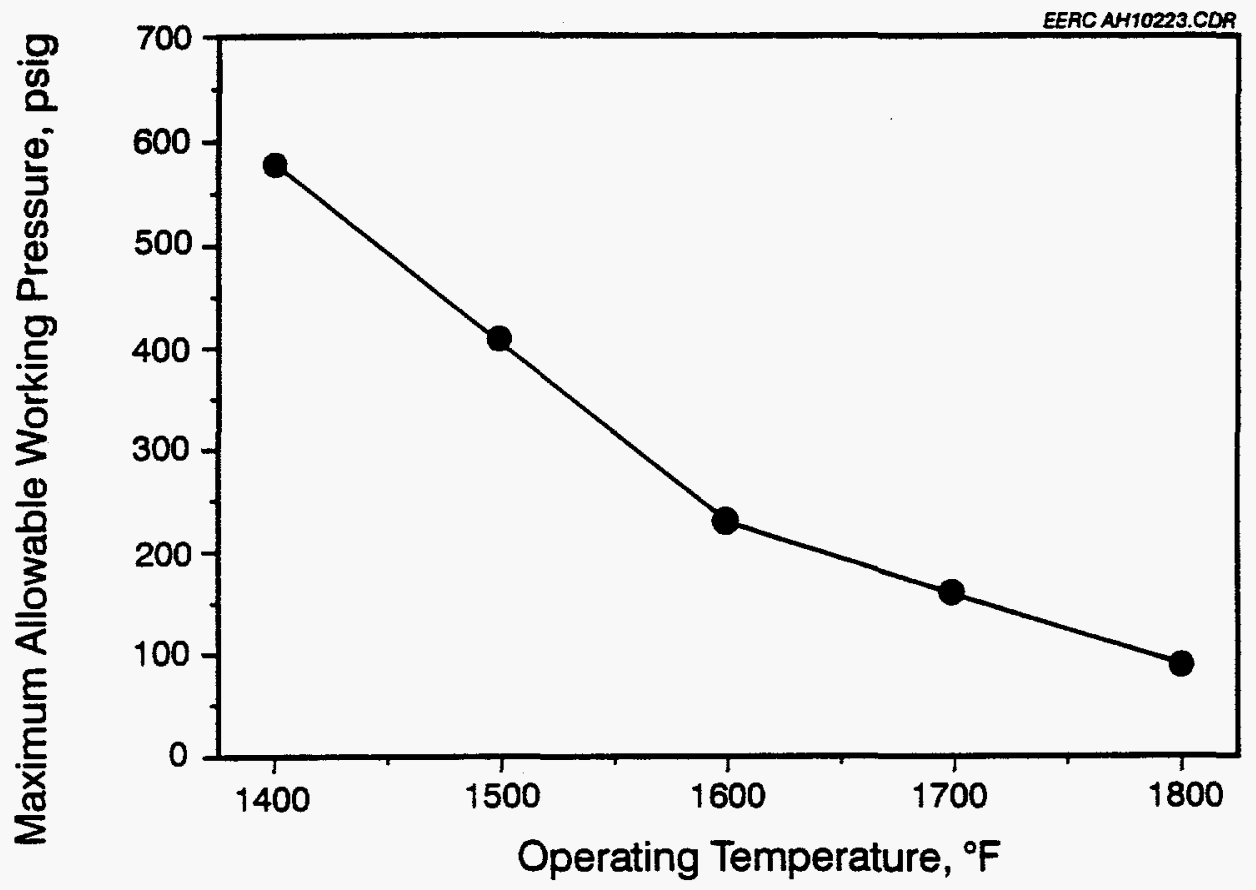

Figure 1. Maximum allowable reactor working pressure over a range of temperatures.

The use of electric heaters provides the capability to match the fuel feed rate to the amount of bed material in the reactor. External heaters are used for heating and maintaining the reactor and hot cyclone at temperatures of up to $2000^{\circ} \mathrm{F}$ for atmospheric operation and up to $1700^{\circ} \mathrm{F}$ for operation at $150 \mathrm{psig}$. The external ceramic heaters on the gas preheater and the reactor itself are rated at 10.8 and $10.05 \mathrm{~kW}$, respectively, with an upper temperature limit of $2200^{\circ} \mathrm{F}$. In a fullscale system, the bed is deep relative to that in the PFBR. Therefore, to keep a similar coal feed rate-to-bed inventory between bench- and full-scale systems, the coal feed rate in the PFBR is kept low relative to that in full-scale systems, compared on a fuel feed rate per bed cross-sectional area basis. Therefore, additional heat is required to maintain the desired temperature. The high heat losses through the reactor walls inherent to small-scale systems also require either good insulation or reactor heating. This type of heating system provides very good control of the reactor temperature. At atmospheric pressure, an in-bed cooling coil can be used to remove excess heat from the high-temperature dense-bed region, allowing for higher fuel feed rates and providing a more uniform overall temperature distribution. The use of both air and nitrogen as fluidizing gas allows excess air and gas velocity to be matched to any design condition.

The bench-scale PFBR is equipped to feed either dry fuel or slurry. Slurry feed is metered with a variable-speed pump. Dry coal and sorbent are metered with separate augers that feed into a common water-cooled auger, which in turn carries the material into the reactor. A bed material hopper empties directly into the common auger without flow control. Each hopper is maintained at a pressure slightly higher than that in the combustor during operation. The hoppers can be isolated from the pressurized system so that they can be refilled during a test. At the bottom of each 


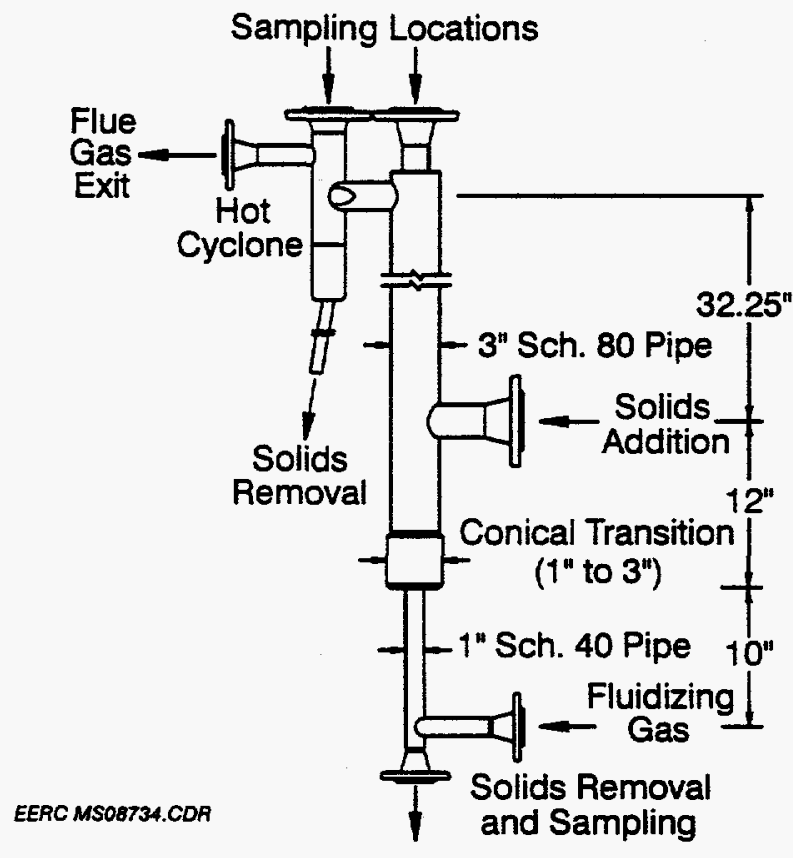

Figure 2. Side view of PFBR.

hopper is a plastic sight tube; in addition, the fuel and sorbent hoppers are equipped with sensors to alert the operator when the hoppers are empty and need to be refilled. A data acquisition and control system is used to monitor and record all critical pressures, temperatures, flow rates, and emissions. These critical data include the gas-flow rates, bed static pressure and differential pressures across the bed and cyclone, and eight different internal reactor temperatures. The air and nitrogen flow rates are controlled automatically to flow rate set points. The reactor pressure is automatically controlled to a pressure set point. The three ceramic heaters on the reactor may be controlled manually to a given heater temperature, or controlled automatically to maintain a desired gas temperature in each zone. Ports for alkali-sampling probes or, alternatively, solid-sampling or gas-sampling probes are located at the top of the reactor and the top of the cyclone. An air-cooled deposition probe is located at the top of the reactor.

\subsection{Alkali-Sampling Probe Description}

An alkali and particulate condensation sampling train has been designed and constructed to allow monitoring of the alkali concentrations in the PFBR. The condensation sampling train was chosen over other techniques at this time because of its relatively low cost to build and operate and its relative simplicity to operate. A disadvantage is the difficulty in collecting a representative sample, especially under reducing conditions, and the delay in obtaining the analytical results. The alkali- sampling train extracts a representative sample from the cyclone outlet of the PFBR. 


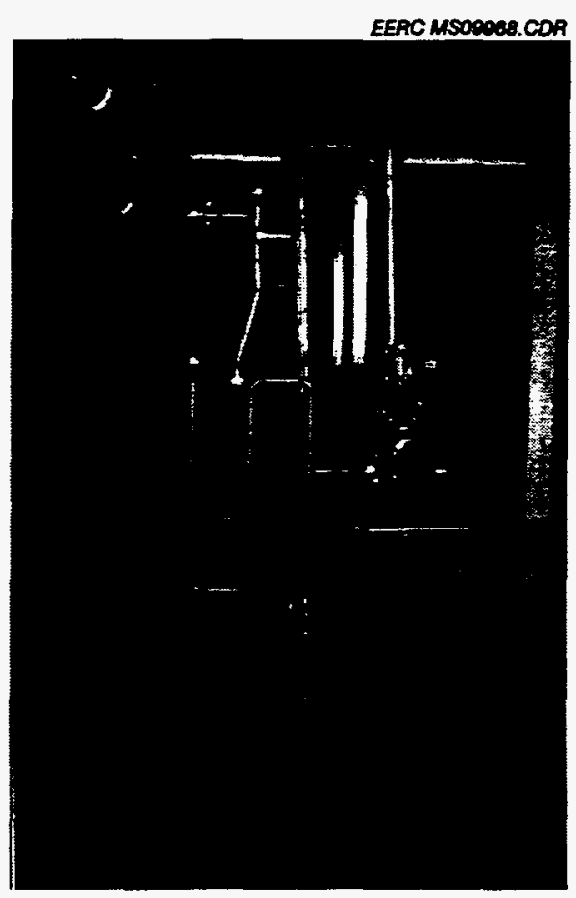

Figure 3. Photograph of PFBR, shown without ceramic heaters.

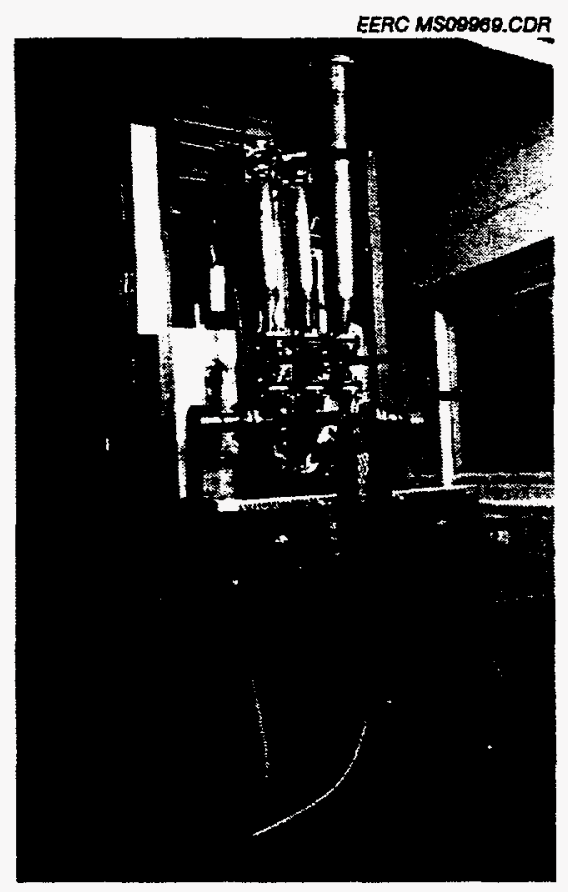

Figure 4. Photograph of PFBR with heaters in place. 
The PFBR alkali-sampling probe consists of a 1.315-in. (0.03-m)-OD stainless steel alkalisampling probe which has been fitted with a small ceramic filter provided by the CeraMem Corporation. The principle behind the sampling probe is to extract a gas sample through a filter that would be representative of the hot-gas filters currently being developed for advanced coal-fired power generation systems. After passing through the ceramic filter maintained at flue gas temperatures, the gases and any vapor-phase alkali species that pass through the filter are cooled and allowed to condense on a high surface area "cold finger." The gas then passes through a final filter to collect any remaining aerosol particles. The gas flows through a series of water bubblers (impingers) to trap any additional alkali vapors and finally flows through pressure and flow measurement and control devices. Figure 5 is a diagram illustrating the alkali-sampling probe and heat exchanger with the impinger train. The high surface area cold finger and the final filter are removed at the end of a test and washed with deionized water to dissolve the alkali species. The washings and the bubbler solutions are analyzed by inductively coupled argon plasma spectroscopy (ICAP) (or other solution analysis techniques) to determine the total amount of alkali collected from the total volume of gas sampled. A cooled knockout pot for collecting coal tars will be needed when sampling from gas streams under reducing conditions (not shown).

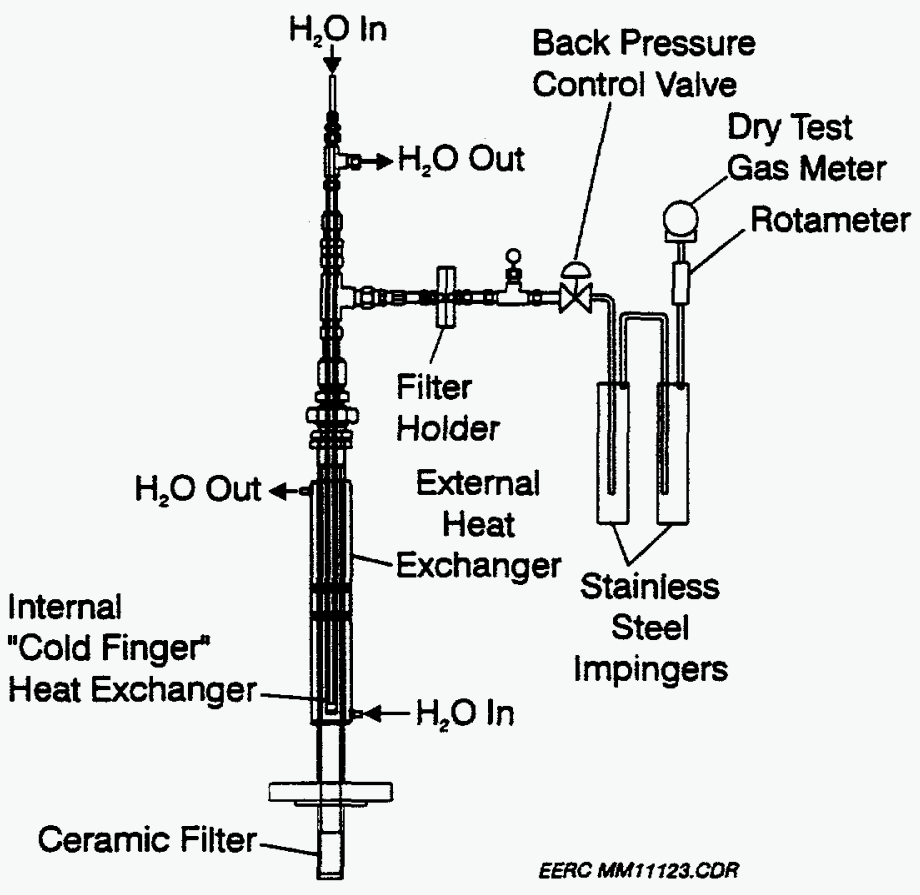

Figure 5. Schematic of alkali-sampling probe. 
Each sampling test is performed for 3.5-4 hours on-line at steady-state conditions to obtain enough sample to establish representative alkali material balances. Initially, this probe is designed to remain permanently in the gas stream, but after the sampling procedure has been proven in short-term combustion tests on the bench-scale PFBR, the probe will be modified to be retractable from a pressurized combustor. This design will allow for sample collection or changing of the probe's ceramic filter while the combustor/gasifier is still in operation. Measuring the volume of rinse solution and the concentration of alkali species in the rinse solution and monitoring the total volume of gas sampled will allow vapor-phase alkali concentration to be calculated in the gas stream.

\subsection{Shakedown Testing of Bench-Scale PFBR}

Shakedown of the reactor, which commenced in 1993, is detailed in the topical report, "Advanced Power Systems, Topical Report Task No. 3.0," Contract No. DE-FC21-93MC30097. This year, additional shakedown followed the installation of a new backpressure control valve and the slurry feed system. The pressure tests with dry feed were conducted with Beulah lignite at a pressure of $150 \mathrm{psig}$ and an average temperature of $1550^{\circ} \mathrm{F}$. Start-up and shutdown procedures for pressurized operation were established.

The slurry feed system was tested with Little Tonzana (Alaska) and Beulah (North Dakota) coal-water fuel (CWF) at $150 \mathrm{psig}$ and $1550^{\circ} \mathrm{F}$. The slurry feed pump is capable of delivering 3-8 lb/hr fuel against a reactor pressure of $150 \mathrm{psig}$. The feed rate is determined in part by the heat input of the fuel; the feed rate must be high enough to deliver enough heat to maintain the desired reactor temperature without exceeding it. While some heat can be made up with the external ceramic heaters, the heaters alone cannot supply full reactor temperature during pressurized operation. A second constraint on the minimum slurry feed rate is that the feed rate must be high enough to keep the material flowing into the reactor: if the feed rate is too low, the slurry will dry out and plug the feed line. The temperature distribution in the reactor was found to be much more uniform with the slurry feed than with a similar fuel fed dry.

Shakedown tests with the as-received (dry) and slurried Knife River lignite were conducted. The analyses of the shakedown fuels are shown in Table 1. During the tests, the flue gas was continuously sampled for $\mathrm{O}_{2}, \mathrm{SO}_{2}, \mathrm{NO}_{x}, \mathrm{~N}_{2} \mathrm{O}, \mathrm{HC}, \mathrm{CO}$, and $\mathrm{CO}_{2}$. No particulate sampling was performed for the test with the dry coal. The flue gas was sampled for volatile organic carbons (VOC), and EPA Method 5 was used to measure particulate in the flue gas for the slurry test. Solid samples include fly ash and bottom ash. The fluidizing gas was a mixture of air and nitrogen, preheated to about $650^{\circ} \mathrm{F}$. Table 2 shows the operating data for the shakedown test with Knife River lignite, the shakedown test with Little Tonzona slurry, and the Knife River slurry test. The heat input for the Knife River slurry was about $38,000 \mathrm{Btu} / \mathrm{hr}$, compared to $31,000 \mathrm{Btu} / \mathrm{hr}$ for the dry Knife River and 29,000 Btu/hr for the Little Tonizona slurry. All three tests were operated at similar temperature, velocity, and excess air levels. Figure 6 shows the temperature distributions for the three tests. The two slurries had very similar temperature distributions, while the dry fuel had a lower bed temperature and higher freeboard temperature.

Table 3 shows the emissions data for the three tests. It is important to remember that the emissions shown in ppm and percent will be low because of the make-up nitrogen added to the combustion air to maintain the desired velocity in the reactor. Figure 7 shows that the $\mathrm{SO}_{2}, \mathrm{NO}_{x}$, 
and $\mathrm{N}_{2} \mathrm{O}$ emissions were relatively steady for the length of the test. Figure 8 compares the emissions, in $\mathrm{lb} / \mathrm{MM}$ Btu, for the three tests. The $\mathrm{SO}_{2}$ emissions were highest for the Little Tonzona slurry, followed by the Knife River slurry. The utilization of inherent alkali for sulfur capture was about $57 \%$ for the Little Tonzona slurry, $65 \%$ for the Knife River slurry, and $78 \%$ for the dry Knife River lignite. $\mathrm{NO}_{\mathrm{x}}$ and $\mathrm{N}_{2} \mathrm{O}$ emissions are greatly influenced by reactor temperature; the relatively high freeboard temperature for the dry Knife River test resulted in higher $\mathrm{NO}_{\mathrm{x}}$ and lower $\mathrm{N}_{2} \mathrm{O}$ emissions than either slurry test. Hydrocarbon emissions were quite low for all three tests.

\section{TABLE 1}

Moisture-Free Fuel Analyses

\begin{tabular}{|c|c|c|c|}
\hline & $\begin{array}{c}\text { Knife } \\
\text { River } \\
\text { Dry }\end{array}$ & $\begin{array}{c}\text { Knife River } \\
\text { Slurry }\end{array}$ & $\begin{array}{c}\text { Little } \\
\text { Tonzona } \\
\text { Slurry }\end{array}$ \\
\hline \multicolumn{4}{|c|}{ Proximate Analysis, $\mathrm{mf}, \mathrm{wt} \%$} \\
\hline Volatiles & 47.3 & 42.8 & 49.71 \\
\hline Fixed Carbon & 41.2 & 467.0 & 40.05 \\
\hline Ash & 11.4 & 10.3 & 10.24 \\
\hline \multicolumn{4}{|c|}{ Ultimate Analysis, mf, wt \% } \\
\hline Hydrogen & 4.4 & 4.6 & 4.39 \\
\hline Carbon & 61.1 & 66.0 & 63.67 \\
\hline Nitrogen & 0.9 & 0.9 & 0.75 \\
\hline Sulfur & 1.6 & 1.5 & 1.42 \\
\hline Oxygen, ind. & 20.5 & 16.7 & 19.53 \\
\hline Ash & 11.4 & 10.3 & 10.24 \\
\hline \multicolumn{4}{|c|}{ Ash Composition, $\%$ as oxides } \\
\hline Calcium, $\mathrm{CaO}$ & 22.6 & 23.5 & 25.3 \\
\hline Magnesium, MgO & 9.1 & 11.2 & 2.7 \\
\hline Sodium, $\mathrm{Na}_{2} \mathrm{O}$ & 3.2 & 0.9 & 0.2 \\
\hline Silica, $\mathrm{SiO}_{2}$ & 25.1 & 22.3 & 27.6 \\
\hline Aluminum, $\mathrm{Al}_{2} \mathrm{O}_{3}$ & 9.7 & 10.7 & 20.5 \\
\hline Ferric, $\mathrm{Fe}_{2} \mathrm{O}_{3}$ & 3.6 & 5.3 & 7.2 \\
\hline Titanium, $\mathrm{TiO}_{2}$ & 0.5 & 0.4 & 0.2 \\
\hline Phosphorous, $\mathrm{P}_{2} \mathrm{O}_{5}$ & 0.4 & 0.4 & 0.5 \\
\hline Potassium, $\mathrm{K}_{2} \mathrm{O}$ & 0.3 & 0.3 & 0.2 \\
\hline Sulfur, $\mathrm{SO}_{3}$ & 25.4 & 24.9 & 15.5 \\
\hline Heating Value, Btu/lb & 10,940 & 11,691 & 10,863 \\
\hline Solids content, $\%$ & $\mathbf{N A}^{1}$ & 55.5 & -53.7 \\
\hline Viscosity, cp & NA & 500 & 500 \\
\hline Moisture content, \% & 31.7 & NA & NA \\
\hline
\end{tabular}

${ }^{1}$ Not applicable. 
TABLE 2

Summary of Process Data

\begin{tabular}{|c|c|c|c|}
\hline Fuel & $\begin{array}{r}\text { Knife } \\
\text { River } \\
\text { Dry }\end{array}$ & $\begin{array}{c}\text { Knife } \\
\text { River } \\
\text { Slurry }\end{array}$ & $\begin{array}{c}\text { Little } \\
\text { Tonzona } \\
\text { Slurry }\end{array}$ \\
\hline Start Time & $11: 36$ & $11: 00$ & $10: 58$ \\
\hline Stop Time & $15: 24$ & $13: 27$ & 13:06 \\
\hline Date & $06-16-94$ & $06-30-94$ & 06-22-94 \\
\hline Fuel Feed Rate, $\mathrm{lb} / \mathrm{hr}$ & 4.34 & 5.88 & 4.96 \\
\hline Fuel Feed Rate, Btu/hr & 31,265 & 38,138 & 28,629 \\
\hline Reactor Pressure, psig & 150.42 & 153.1 & 151.2 \\
\hline Reactor Pressure Drop, in. $\mathrm{H}_{2} \mathrm{O}$ & 13.87 & 11.4 & 11.5 \\
\hline Cyclone Pressure Drop, in. $\mathrm{H}_{2} \mathrm{O}$ & 14.53 & 4.4 & 10.9 \\
\hline \multicolumn{4}{|l|}{ Fluidizing Gas, scfm } \\
\hline Air & 11 & 11.26 & 10.23 \\
\hline Nitrogen & 11.5 & 11.01 & 12.27 \\
\hline Total & 22.5 & 22.27 & 22.5 \\
\hline \multicolumn{4}{|l|}{ Flue Gas } \\
\hline $\mathrm{O}_{2}, \%$ & 4.8 & 4.5 & 4.8 \\
\hline $\mathrm{CO}_{2}, \%$ & 4.2 & 4.7 & 3.7 \\
\hline $\mathrm{CO}, \mathrm{lb} / \mathrm{MMBtu}$ & 0.007 & 0.001 & 0.010 \\
\hline $\mathrm{SO}_{2}, \mathrm{lb} / \mathrm{MMBtu}$ & 0.617 & 0.883 & 1.055 \\
\hline $\mathrm{NO}_{\mathrm{x}}, \mathrm{lb} / \mathrm{MMBtu}$ & 0.387 & 0.242 & 0.273 \\
\hline $\mathrm{N}_{2} \mathrm{O}, \mathrm{lb} / \mathrm{MMBtu}$ & 0.053 & 0.118 & 0.131 \\
\hline Hydrocarbons, lb/MMBtu & 0.016 & 0.035 & 0.039 \\
\hline Excess Air, \% & 23.4 & 21.9 & 23.2 \\
\hline Sulfur Retention, \% & 80.0 & 65.0 & 60.0 \\
\hline FG SGV $1, \mathrm{ft} / \mathrm{sec}$ & 2.95 & 2.94 & 2.91 \\
\hline \multicolumn{4}{|l|}{ Reactor Temperatures } \\
\hline Preheater Exit & 662 & 649 & 652 \\
\hline Plenum & 927 & 813 & 943 \\
\hline $0.25 \mathrm{in.}$ & 1394 & 1345 & 1396 \\
\hline 1.75 in. & 1419 & 1493 & 1459 \\
\hline 3.5 in. & 1409 & 1511 & 1461 \\
\hline $5.0 \mathrm{in.}$ & 1415 & 1522 & 1474 \\
\hline 7.0 in. & 1426 & 1529 & 1476 \\
\hline 9.0 in. & 1442 & 1524 & 1472 \\
\hline 11.0 in. & 1462 & $\mathrm{NA}^{2}$ & NA \\
\hline 15.0 in & 1522 & 1568 & 1526 \\
\hline 23.0 in & 1728 & 1642 & 1650 \\
\hline $31.0 \mathrm{in.}$ & 1733 & 1616 & 1634 \\
\hline 43.25 in. & 1672 & 1556 & 1559 \\
\hline Average & 1523 & 1551 & 1523 \\
\hline Cyclone Exit & 1428 & 1432 & 1392 \\
\hline
\end{tabular}

${ }^{1}$ Flue gas superficial gas velocity.

${ }^{2}$ Not available - slurry feed enters the reactor through this thermocouple port. 


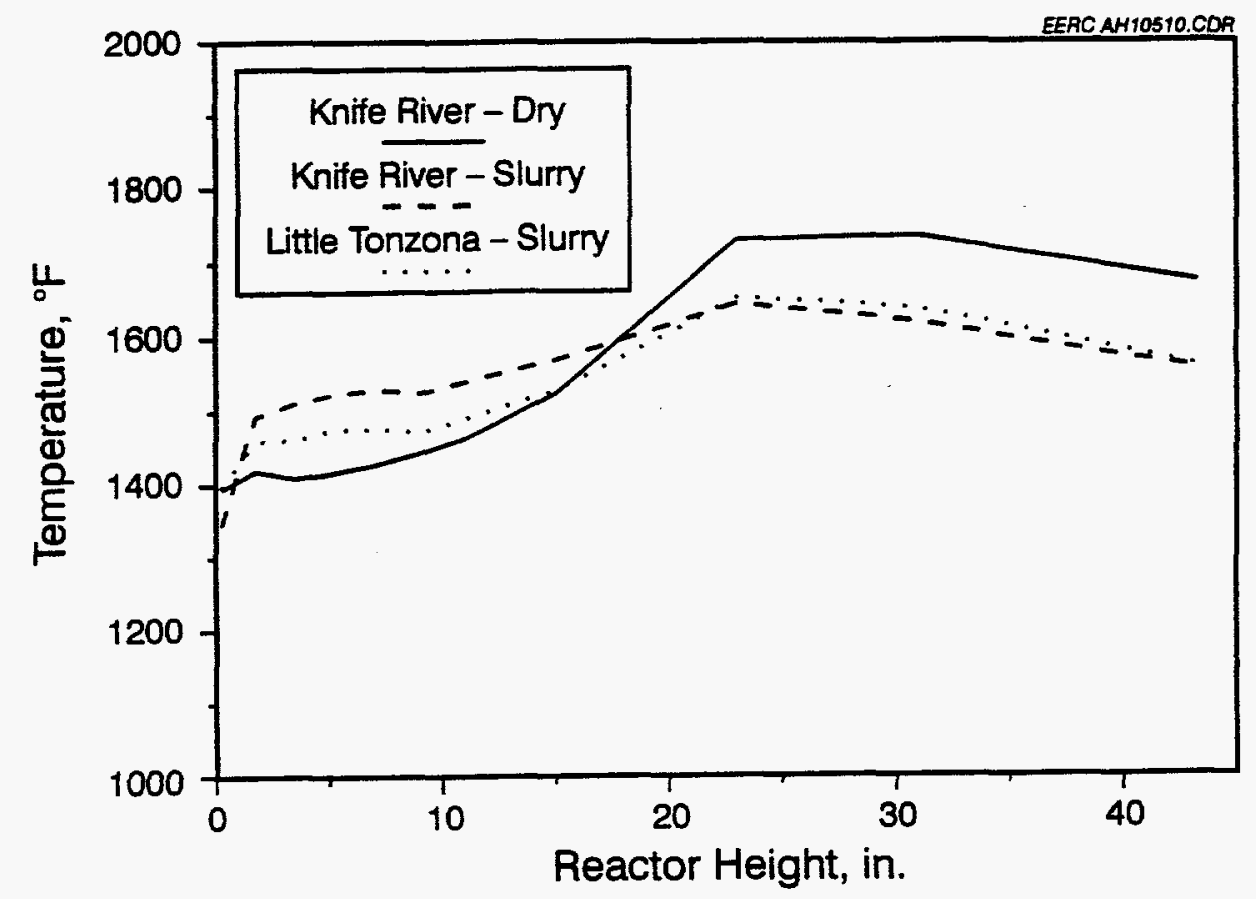

Figure 6. Temperature distributions for dry Knife River, Knife River slurry, and Little Tonzona slurry.

TABLE 3

Emissions Data

\begin{tabular}{|c|c|c|c|}
\hline Parameter & Knife River Dry & Knife River Slurry & Little Tonzona Slurry \\
\hline $\begin{array}{l}\mathrm{O}_{2}, \% \\
\text { Excess Air, \% }\end{array}$ & $\begin{array}{r}4.80 \\
23.42\end{array}$ & $\begin{array}{l}4.52 \\
21.9\end{array}$ & $\begin{array}{r}4.79 \\
23.20\end{array}$ \\
\hline $\begin{array}{l}\text { CO Content, ppm } \\
\text { CO Emission, lb/MMBtu }\end{array}$ & $\begin{array}{r}2 \\
0.007\end{array}$ & $\begin{array}{r}1 \\
0.001\end{array}$ & $\begin{array}{r}3 \\
0.010\end{array}$ \\
\hline $\mathrm{CO}_{2}$ Content, $\%$ & 4.2 & 4.7 & 3.7 \\
\hline $\begin{array}{l}\mathrm{NO}_{\mathrm{x}} \text { Content, ppm } \\
\mathrm{NO}_{\mathrm{x}} \text { Emission, lb/MMBtu }\end{array}$ & $\begin{array}{r}73 \\
0.387\end{array}$ & $\begin{array}{r}53 \\
0.242\end{array}$ & $\begin{array}{r}44 \\
0.273\end{array}$ \\
\hline $\begin{array}{l}\mathrm{N}_{2} \mathrm{O} \text { Content, } \mathrm{ppm} \\
\mathrm{N}_{2} \mathrm{O} \text { Emission, } \mathrm{lb} / \mathrm{MMBtu}\end{array}$ & $\begin{array}{r}10 \\
0.053\end{array}$ & $\begin{array}{r}27 \\
0.118\end{array}$ & $\begin{array}{r}22 \\
0.131\end{array}$ \\
\hline $\begin{array}{l}\text { HC Content, ppm } \\
\text { HC Emission, lb/MMBtu }\end{array}$ & $\begin{array}{r}1 \\
0.016\end{array}$ & $\begin{array}{r}1 \\
0.035\end{array}$ & $\begin{array}{r}0.3 \\
0.039\end{array}$ \\
\hline $\begin{array}{l}\mathrm{SO}_{2} \text { Content, } \mathrm{ppm} \\
\mathrm{SO}_{2} \text { Emission, lb/MMBtu } \\
\mathrm{SO}_{2} \text { Retention, \% }\end{array}$ & $\begin{array}{r}83 \\
0.617 \\
80.0\end{array}$ & $\begin{array}{r}139 \\
0.883 \\
65.0\end{array}$ & $\begin{array}{r}122 \\
1.055 \\
60.0\end{array}$ \\
\hline $\begin{array}{l}\text { Alkali-to-Sulfur Ratio } \\
\text { Alkali Utilization }\end{array}$ & $\begin{array}{l}1.02 \\
78.5\end{array}$ & $\begin{array}{l}0.97 \\
67.3\end{array}$ & $\begin{array}{l}1.05 \\
57.1\end{array}$ \\
\hline Avg. Comb. Temp., ${ }^{\circ} \mathrm{F}$ & 1523 & 1551 & 1523 \\
\hline
\end{tabular}




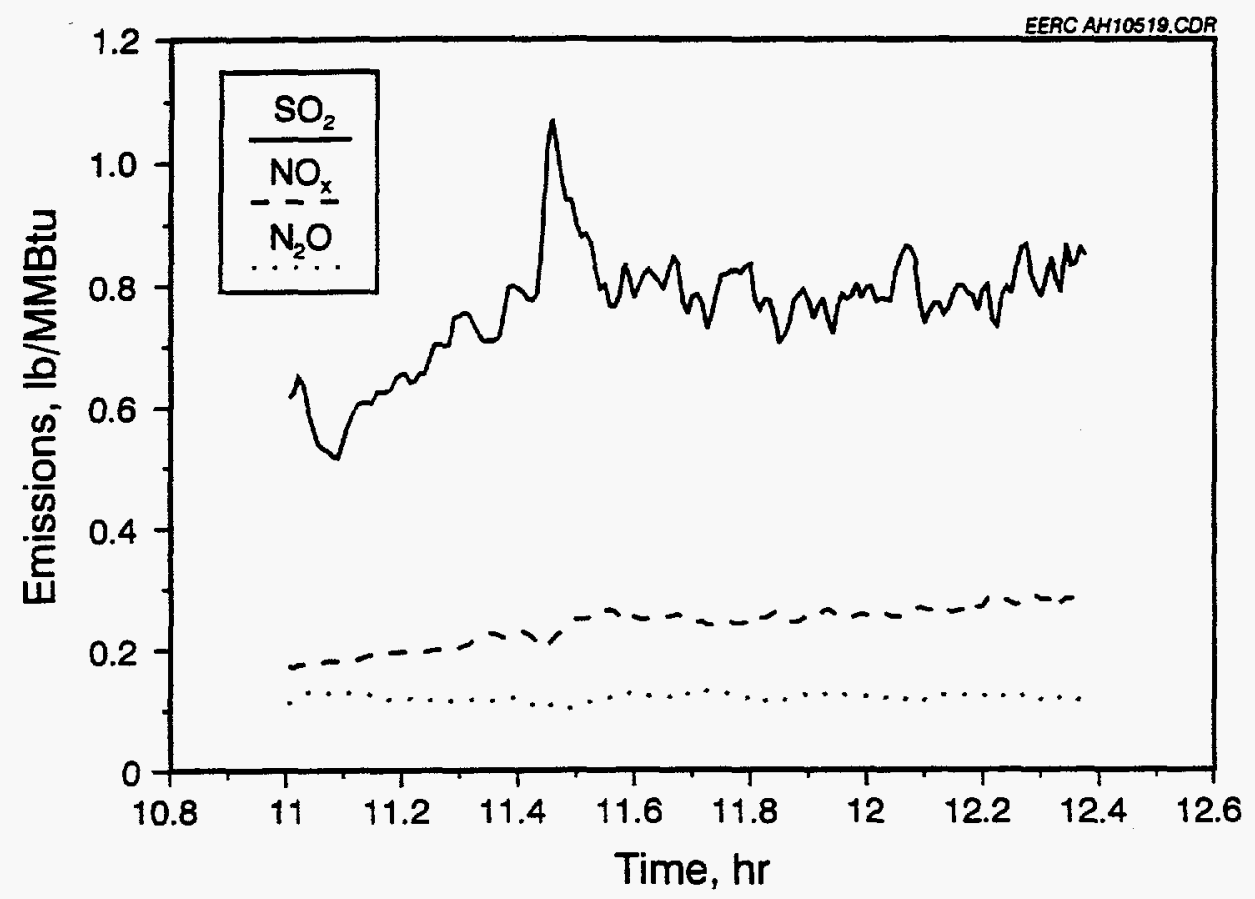

Figure 7. Flue gas emissions over time for Knife River slurry.

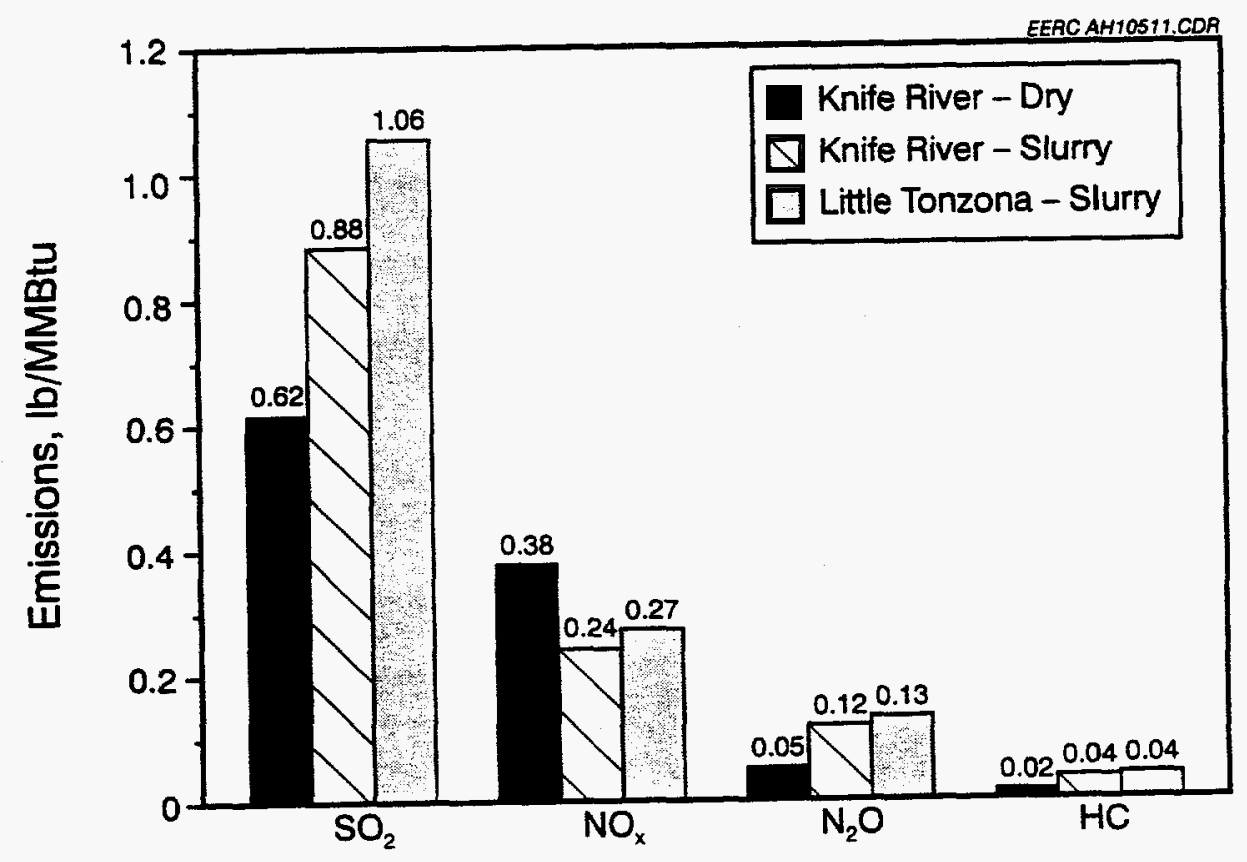

Figure 8. Comparison of flue gas emissions for three tests. 


\subsection{Results from Alkali Sampling}

Several alkali sampling tests have been completed. The first test utilized a Beulah-Zap coal (North Dakota lignite), which is considered to be a high-sodium coal, while the second test utilized a low-sodium Blacksville coal (Pittsburgh No. 8 bituminous coal). Both coals were fed using the dry feeder. Table 4 shows the results of proximate, ultimate, and $\mathrm{X}$-ray fluorescence (XRF) analyses of these two coals as utilized in these combustion tests, as well as a sorbent used on later testing. Table 5 shows the gas composition of six trace species from these combustion tests.

The results from these analyses are consistent with those expected for these fuels. The higher sodium levels in the lignite coal resulted in higher sodium levels in the flue gas, while the bituminous fuel had higher potassium and chlorine levels than those in the lignite fuel. The high iron concentrations are probably due to the pyritic sulfur present in both fuels.

Table 6 shows the results of XRF analyses obtained from the filter located immediately after the alkali-sampling probe. The green sludge material is primarily a hydrated iron sulfate or sulfite material. The high iron levels appear to come from the small quantity of iron present in the coal ash.

Three subsequent tests utilizing a Beulah lignite and an inert silica sand bed material were completed at essentially the same operating conditions. The first test was a repeat of the baseline lignite test and demonstrated good repeatability in the technique. Two tests utilized a kaolin clay as an alkali getter to capture vapor-phase alkali species. The kaolin was mixed with the crushed Beulah lignite, in the ratio of 1 part kaolin to 2 parts ASTM coal ash.

Kaolin is a clay composed primarily of the mineral kaolinite $\left(\mathrm{Al}_{2} \mathrm{Si}_{2} \mathrm{O}_{5}[\mathrm{OH}]_{4}\right)$. It was preferred for the gettering test over other types of clays because kaolin can be found in relatively pure form, containing less alkali and alkaline-earth elements which may flux the material upon heating. Also, kaolinite has a layered structure composed of a sheet of silica tetrahedra bonded on one side to a sheet of aluminum hydroxide octahedra, so it has a higher aluminum-to-silicon ratio that most other clays. Because of its higher aluminum content and thus possible fusion with an ash deposit, the viscosity of the deposit will usually increase, thereby weakening it. Kaolin is mined in a number of places in the United States and can be supplied in rock, dried powder, or sieved dried powder forms. The kaolin used for these tests was provided as rock by J.M. Huber Corporation of Macon, Georgia.

One test utilized kaolin sized at $-1 / 8$ in. to +30 mesh, while the other utilized a particle size of -30 mesh. A $77 \%$ reduction in sodium was noted using the larger-sized kaolin and a $93 \%$ reduction using the finer-sized kaolin. Final sodium levels were 840 and $270 \mathrm{ppb}$ for the $-1 / 8$-in. and -30 -mesh, respectively.

The higher surface area of the smaller-sized kaolin facilitated the improved sodium gettering, but the level of $270 \mathrm{ppb}$ is still above that recommended by turbine manufactures. These results do indicate, however, that significant reduction in alkali can be obtained using in-bed getters. Sulfur retention for the tests using kaolin was lower than that for the test without kaolin. Capturing the sodium with the kaolin left less of the sodium available for sulfur capture. Future work will focus 
Beulah Lignite, and Plum Run Dolomite

\begin{tabular}{lccc}
\hline $\begin{array}{l}\text { Mine Name: } \\
\text { Type: }\end{array}$ & $\begin{array}{c}\text { Blacksville } \\
\text { Bituminous }\end{array}$ & $\begin{array}{c}\text { Beulah } \\
\text { Lignite }\end{array}$ & $\begin{array}{c}\text { Phum Run } \\
\text { Dolomite }\end{array}$ \\
\hline $\begin{array}{l}\text { Proximate, mf, wt\% } \\
\text { Volatile Matter }\end{array}$ & 37.7 & & NA \\
Fixed Carbon & 49.6 & 45.6 & NA \\
Ash & 12.7 & 37.0 & NA \\
Ultimate, mf, wt\% & & 17.4 & \\
Carbon & 70.1 & & NA \\
Hydrogen & 5.0 & 56.8 & NA \\
Nitrogen & 1.4 & 3.5 & NA \\
Sulfur & 2.8 & 0.7 & NA \\
Oxygen, ind & 8.0 & 3.1 & NA \\
Ash & 12.7 & 18.5 & NA \\
Ash Composition, \% as oxides & & 17.4 & 0.6 \\
$\mathrm{SiO}_{2}$ & 46.9 & & 0.4 \\
$\mathrm{Al}_{2} \mathrm{O}_{3}$ & 21.0 & 24.5 & 1.1 \\
$\mathrm{Fe}_{2} \mathrm{O}_{3}$ & 23.2 & 11.4 & 0.0 \\
$\mathrm{TiO}_{2}$ & 0.8 & 19.1 & 0.0 \\
$\mathrm{P}_{2} \mathrm{O}_{5}$ & 0.6 & 71.2 \\
$\mathrm{CaO}$ & 0.2 & 0.3 & 26.0 \\
$\mathrm{MgO}_{\mathrm{Na}} \mathrm{O}$ & 1.8 & 12.0 & 0.2 \\
$\mathrm{~K}_{2} \mathrm{O}$ & 1.8 & 6.9 & 0.2 \\
$\mathrm{SO}_{3}$ & 0.3 & 3.4 & 0.2 \\
$\mathrm{Heating}$ Value, Btu/lb & 1.5 & 0.1 & NA \\
\hline
\end{tabular}

TABLE 5

Operating Conditions and Gas-Phase Species Composition for Alkali Gettering Tests

\begin{tabular}{|c|c|c|c|c|c|}
\hline $\begin{array}{l}\text { PFB Run: } \\
\text { Coal Name: } \\
\text { Coal Type: } \\
\text { Sorbent Name: } \\
\text { Sorbent Type: }\end{array}$ & $\begin{array}{c}\text { BLK-PR01A } \\
\text { Blacksville } \\
\text { Bituminous } \\
\text { Phum Run } \\
\text { Dolomite } \\
\end{array}$ & $\begin{array}{c}\text { B13-0894 } \\
\text { Beulah } \\
\text { Lignite } \\
\text { Plum Run } \\
\text { Dolomite } \\
\end{array}$ & $\begin{array}{c}\text { B14-1294 } \\
\text { Beulah } \\
\text { Lignite } \\
\text { None } \\
\text { None } \\
\end{array}$ & $\begin{array}{c}\text { B15-1294 } \\
\text { Beulah } \\
\text { Lignite } \\
-1 / 8 \text { in. } \\
\text { Kaolin } \\
\end{array}$ & $\begin{array}{c}\text { B16-1394 } \\
\text { Beulah } \\
\text { Lignite } \\
-30 \text { mesh } \\
\text { Kaolin } \\
\end{array}$ \\
\hline \multicolumn{6}{|l|}{ Operating Conditions } \\
\hline Temperature, ${ }^{\circ} \mathbf{F}$ & 1600 & 1550 & 1514 & 1544 & 1543 \\
\hline Pressure, psig & 125 & 150 & 150 & 150 & 150 \\
\hline FG SGV, $\mathrm{tt} / \mathrm{sec}$ & 2.8 & 3.0 & 2.8 & 2.9 & 2.9 \\
\hline Excess Air, \% & 25 & 25 & 25.1 & 26.2 & 24.9 \\
\hline Sulfur Retention, \% & 53.9 & 90.0 & 78.1 & 55.0 & 62.0 \\
\hline \multicolumn{6}{|c|}{ Gas Species Concentration, Ppm } \\
\hline $\mathrm{Na}$ & 0.64 & 3.00 & 3.61 & 0.84 & 0.27 \\
\hline $\mathbf{K}$ & 0.41 & $<0.19$ & $<0.11$ & $<0.13$ & $<0.13$ \\
\hline SO $_{4}$ & 136 & 95.3 & 106.0 & 64.3 & 82.6 \\
\hline $\mathrm{Cl}$ & 11.0 & 2.97 & 3.0 & 0.56 & 0.68 \\
\hline $\mathrm{Fe}$ & 32.3 & 34.9 & 54.0 & 20.8 & 31.3 \\
\hline
\end{tabular}


TABLE 6

XRF Analysis of Filter Material Collected from AlkaliSampling Probe During Test BLK-PR01A

\begin{tabular}{lcc}
\hline Oxide Component, wt $\%$ & Normalized XRF & Normalized, SO $_{3}$-free \\
\hline $\mathrm{SiO}_{2}$ & 8.4 & 22.4 \\
$\mathrm{Al}_{2} \mathrm{O}_{3}$ & 0.7 & 1.9 \\
$\mathrm{Fe}_{2} \mathrm{O}_{3}$ & 25.3 & 67.4 \\
$\mathrm{TiO}_{2}$ & 0.2 & 0.5 \\
$\mathrm{P}_{2} \mathrm{O}_{5}$ & 1.4 & 3.8 \\
$\mathrm{CaO}$ & 0.0 & 0.0 \\
$\mathrm{MgO}$ & 1.5 & 4.0 \\
$\mathrm{Na}$ & 0.0 & 0.0 \\
$\mathrm{~K}_{2} \mathrm{O}$ & 0.1 & 0.1 \\
$\mathrm{SO}_{3}$ & 62.4 & - \\
Total & 100.0 & 100.1 \\
\hline
\end{tabular}

on establishing optimum conditions for in-bed alkali gettering and identifying getters that result in the most alkali capture for the least cost.

\subsection{Results from Sulfur Sorbent Performance Tests}

The first of a series of conventional sulfur sorbents has been tested in the PFBR. The performance of Plum Run dolomite as a sulfur sorbent has been characterized over a range of operating conditions. The coal and dolomite were the same as those used in the Tidd commercial PFBC and allowed for some comparison of data. The emission performance under the various operating conditions is reported in this paper. Ongoing work will characterize additional sorbents. In addition, work will focus on developing an accurate predictive technique for evaluating sorbent performance. The information and models developed will be used to suggest strategies to optimize sorbent performance. The parameters include sorbent selection, sizing, and conditions of operation. These sorbents will also be characterized in the PFBR to determine their propensity to break down in the PFBC.

Sorbent characterization test procedures include preheating the PFBR with the electric heaters, augering in inert silica sand bed material, and establishing air, nitrogen, and reactor pressure before starting the coal feed to the reactor. Initially, a steady-state condition using a Pittsburgh No. 8 bituminous coal and elemental sulfur mixture was established using a dry feed. The elemental sulfur was added to the coal to provide an artificially high $\mathrm{SO}_{2}$ concentration in the flue gas which allowed the impact of sulfur to be studied without changing the coal. These $\mathrm{SO}_{2}$ concentrations were approximately 1500,3000 , and $4500 \mathrm{ppm}$ uncorrected for nitrogen dilution. After a baseline was established, the coal feed was changed to a Pittsburgh No. 8, elemental sulfur, and dolomite mixture. This mixture was the same as the baseline mixture except for the addition of dolomite to obtain a desired $\mathrm{Ca}: \mathrm{S}$ ratio. The decrease in the observed $\mathrm{SO}_{2}$ concentration was attributed to the sulfur capture capability of the dolomite sorbent at the given bed conditions. 
The test matrix utilized for these tests is given in Table 7. The actual test conditions and results from the first series of tests utilizing the Plum Run dolomite and Pittsburgh No. 8 coal are presented in Table 8. The coal and dolomite properties are presented in Table 4. Figure 9 shows the impact of operating conditions on sulfur capture. Trends shown on the curve are an increase in sulfur retention with increasing calcium-to-sulfur ratio, decreasing pressure, and increasing $\mathrm{SO}_{2}$ level in the flue gas. Data from the Tidd PFBC are shown on the curve for comparison purposes. The overall sulfur retention is low for the bench-scale tests, most likely because of the shallow bed, which results in a very short residence time. Future work will generate similar data for five additional sorbents, and comparisons will be made to full-scale data. The result will be a series of curves that determine the same relative differences as those obtained in the full scale. If the bench scale can reflect the differences noted at the full scale, then the PFBR can become a useful tool for evaluating sorbent performance.

The impact of operating conditions on $\mathrm{NO}_{x}$ emissions is not as well defined. Figure 10 is a graph showing $\mathrm{NO}_{x}$ emissions versus bed temperature. Generally, these results indicate decreasing $\mathrm{NO}_{x}$ with increasing $\mathrm{SO}_{2}$ levels in the flue gas, decreasing calcium-to-sulfur ratio, increasing temperature, and increasing pressure. Of concern is the trend of decreasing $\mathrm{NO}_{\mathrm{x}}$ with increasing temperature. Because some researchers have noted little effect of temperature on $\mathrm{NO}_{\mathrm{x}}$ emissions over this temperature range, a significant decease in $\mathrm{NO}_{\mathrm{x}}$ was not expected (1). This phenomenon will be investigated more in the future.

Nitrous oxide measurements were also taken during this work. Figure 11 shows the results. In contrast to the $\mathrm{NO}_{x}$ results, the trends exhibited for the $\mathrm{N}_{2} \mathrm{O}$ emissions were very distinct. $\mathrm{N}_{2} \mathrm{O}$ emissions decreased sharply as temperature increased. Emissions were slightly lower at higher pressures and higher $\mathrm{SO}_{2}$ concentrations. These levels were lower than those measured from other pilot-scale atmospheric fluid-bed combustors at the EERC (2). Future testing will establish baseline readings at atmospheric pressure with the PFBR for direct comparison.

\section{TABLE 7}

Test Matrix for Sulfur Sorbent Characterization

\begin{tabular}{|c|c|c|c|c|c|c|c|c|c|}
\hline Test Number & $\overline{0}$ & 1 & 2 & 3 & 4 & 5 & 6 & 7 & 8 \\
\hline Temp, ${ }^{\circ} \mathrm{F}$ & 0 & - & - & - & + & - & + & + & + \\
\hline Press., psig & 0 & + & - & + & - & - & - & + & + \\
\hline $\mathrm{SO}_{2}, \mathrm{ppm}$ & 0 & - & - & + & + & + & - & + & - \\
\hline $\mathrm{Ca}: \mathrm{S}$ & 0 & $t$ & - & - & - & + & + & -+ & - \\
\hline
\end{tabular}

\begin{tabular}{lrrr} 
& \multicolumn{3}{c}{ Key to Symbols } \\
& - & 0 & + \\
Temp, ${ }^{\circ} \mathrm{F}$ & 1500 & 1600 & 1700 \\
Press., psig & 100 & 125 & 150 \\
$\mathrm{SO}_{2}$, ppm & 1500 & 3000 & 4500 \\
$\mathrm{Ca}: S$ & 1.5 & 2.25 & 3.0 \\
\hline
\end{tabular}




\section{TABLE 8}

Operating Data and Emissions from Sulfur Sorbent Characterization Tests ${ }^{1}$

\begin{tabular}{|c|c|c|c|c|c|c|c|c|c|c|c|c|}
\hline Temp., ${ }^{\circ} \mathrm{F}$ & $\begin{array}{l}\text { Freeboard } \\
\text { Temp., }{ }^{\circ} \mathrm{F} \\
\end{array}$ & $\begin{array}{c}\text { Pressure, } \\
\text { psia }\end{array}$ & $\begin{array}{l}\text { Excess } \\
\text { Air, \% } \\
\end{array}$ & $\begin{array}{c}\text { Velocity, } \\
\text { ft/sec }\end{array}$ & $\begin{array}{c}\text { Added } \mathrm{SO}_{2}, \\
\mathrm{ppm}\end{array}$ & $\begin{array}{l}\mathrm{Ca} / \mathrm{S} \text { Molar } \\
\text { Ratio }\end{array}$ & $\begin{array}{c}\text { S Ret., } \\
\% \\
\end{array}$ & $\begin{array}{c}\mathrm{NO}_{x}, \\
\text { lb/MMBtu }\end{array}$ & $\begin{array}{l}\mathrm{NO}_{\mathrm{x}}, \\
\mathrm{ppm}\end{array}$ & $\begin{array}{c}\mathrm{N}_{2} \mathrm{O} \\
\text { Ib/MMBtu } \\
\end{array}$ & $\begin{array}{l}\mathrm{N}_{2} \mathrm{O} \text {, } \\
\text { ppm }\end{array}$ & $\begin{array}{l}\text { Label for } \\
\text { Figures }\end{array}$ \\
\hline 1594 & 1704 & 139 & 24.4 & 1.54 & 3032 & 2.25 & 47.3 & 0.323 & 203 & 0.004 & 2.6 & 0000 \\
\hline 1497 & 1551 & 164 & 24.1 & 1.63 & 1414 & 3 & 39.9 & 0.574 & 425 & 0.160 & 124 & tPsC \\
\hline 1504 & 1556 & 115 & 21.9 & 1.84 & 1329 & 1.5 & 16.9 & 0.476 & 294 & 0.176 & 114 & tpsc \\
\hline 1486 & 1553 & 164 & 28.0 & 1.82 & 4716 & 1.5 & 40.8 & 0.368 & 241 & 0.138 & 95 & tPSc \\
\hline 1650 & 1752 & 114 & 34.3 & 1.81 & 4073 & 1.5 & 50.1 & 0.254 & 205 & 0.019 & 16 & TpSc \\
\hline 1468 & 1556 & 115 & 25.7 & 1.79 & 4862 & 3 & 73.3 & 0.386 & 333 & 0.155 & 141 & tpSC \\
\hline 1675 & 1734 & 115 & 24.1 & 1.82 & 1292 & 3 & 44.3 & 0.322 & 205 & 0.040 & 26 & TpsC \\
\hline 1606 & 1763 & 164 & 21.7 & 1.74 & 4946 & 3 & 66 & 0.162 & 152 & 0.011 & 10 & TPSC \\
\hline 1657 & 1779 & 164 & 26.2 & 1.71 & 2367 & 1.5 & 7.3 & 0.226 & 162 & NA & NA & TPsc \\
\hline 1536 & $\mathrm{NA}^{2}$ & 116 & NA & NA & NA & 2.88 & 89.4 & NA & NA & NA & NA & (Tidd) tp \\
\hline 1537 & NA & 114 & NA & NA & NA & 3.93 & 94 & NA & NA & NA & NA & (Tidd) tp \\
\hline
\end{tabular}

1 Plum Run dolomite used in all tests. Blacksville bituminous (Pittsburgh No. 8) fired for all tests. Tidd uses Plum Run dolomite sorbent and Pittsburgh No. 8 fuel.

${ }^{2}$ Not available. 


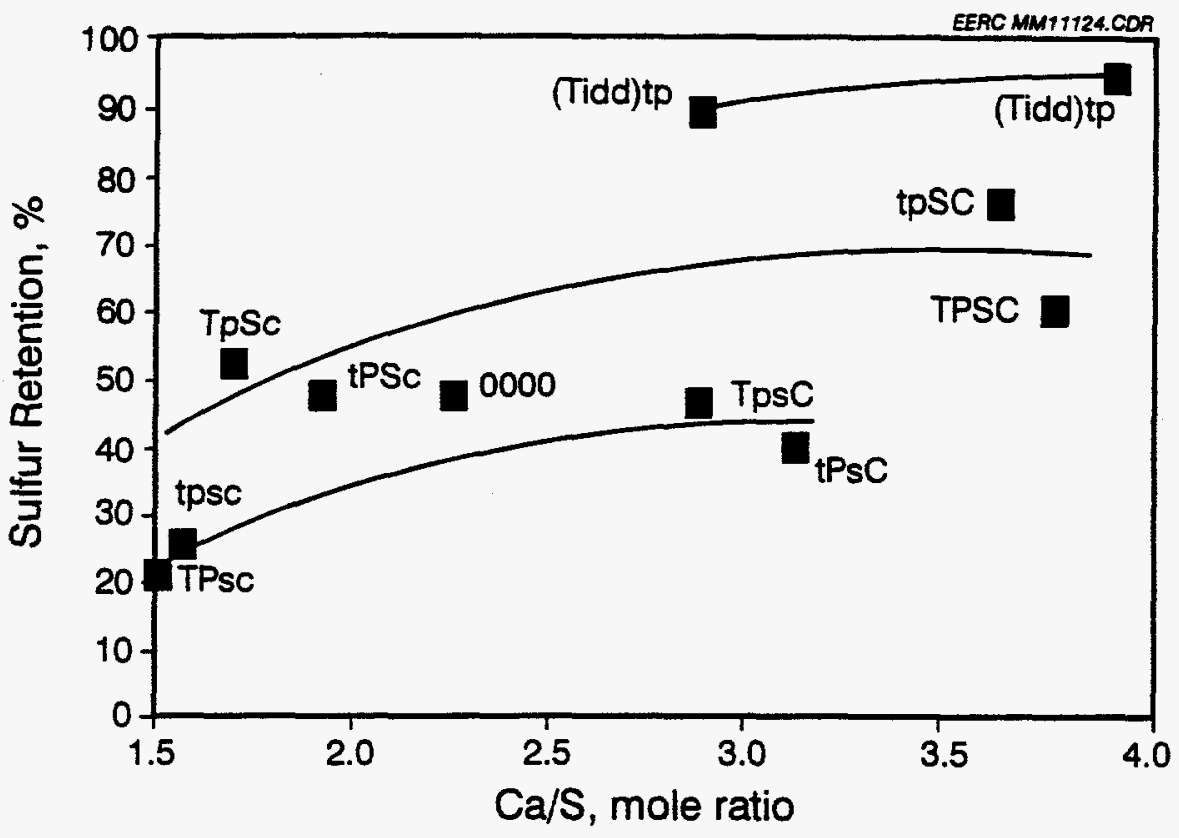

Figure 9. Sulfur capture in the PFBR as a function of operating conditions.

\subsection{Results from Refuse-Derived Fuel and Lignite Combustion Tests}

Slurries of carbonized refused-derived fuel (RDF) and lignite were burned in the PFBR. These tests accomplished several objectives, including demonstrating that slurries could be burned in the PFBR, characterizing performance of the fuels, and investigating the fate of RCRA heavy metals in PFBC. The properties of the fuels used for these tests are given in Table 9.

The average operating conditions obtained from the combustion tests of a Knife River lignite slurry fuel, a pure RDF slurry fuel, and a RDF-Knife River lignite slurry fuel mixed in a ratio to supply a sulfur-compliant fuel are shown in Table 10. The desired operating conditions for these tests were to be $1550^{\circ} \mathrm{F}, 150 \mathrm{psig}, 3.0 \mathrm{feet} / \mathrm{second}$ reactor velocity, and $25 \%$ excess air, with an initial bed of silica sand. The average operating conditions obtained are shown in Table 10. The temperature distribution inside the PFBR is shown in Figure 12. The average reactor temperature increased in the reactor freeboard when the fuel was changed from the Knife River lignite to the RDF slurry fuel to the RDF-lignite fuel. While some correlation exists between the freeboard temperature and the heat rate of the lignite fuel fed to the PFBR, the correlation is not strong. Rather, these trends suggest that the greater amount of volatile matter in the RDF and the RDF-lignite mixture results in more burning in the freeboard. Thus, more of the fuel combustion occurs in the freeboard area, resulting in the higher temperatures seen in those zones. The increased energy density (i.e., reduced water content) of the RDF-lignite blend (7143 Btu/lb) versus that of the lignite alone ( $6466 \mathrm{Btu} / \mathrm{lb})$ is also partly responsible for the temperature differences noted. 


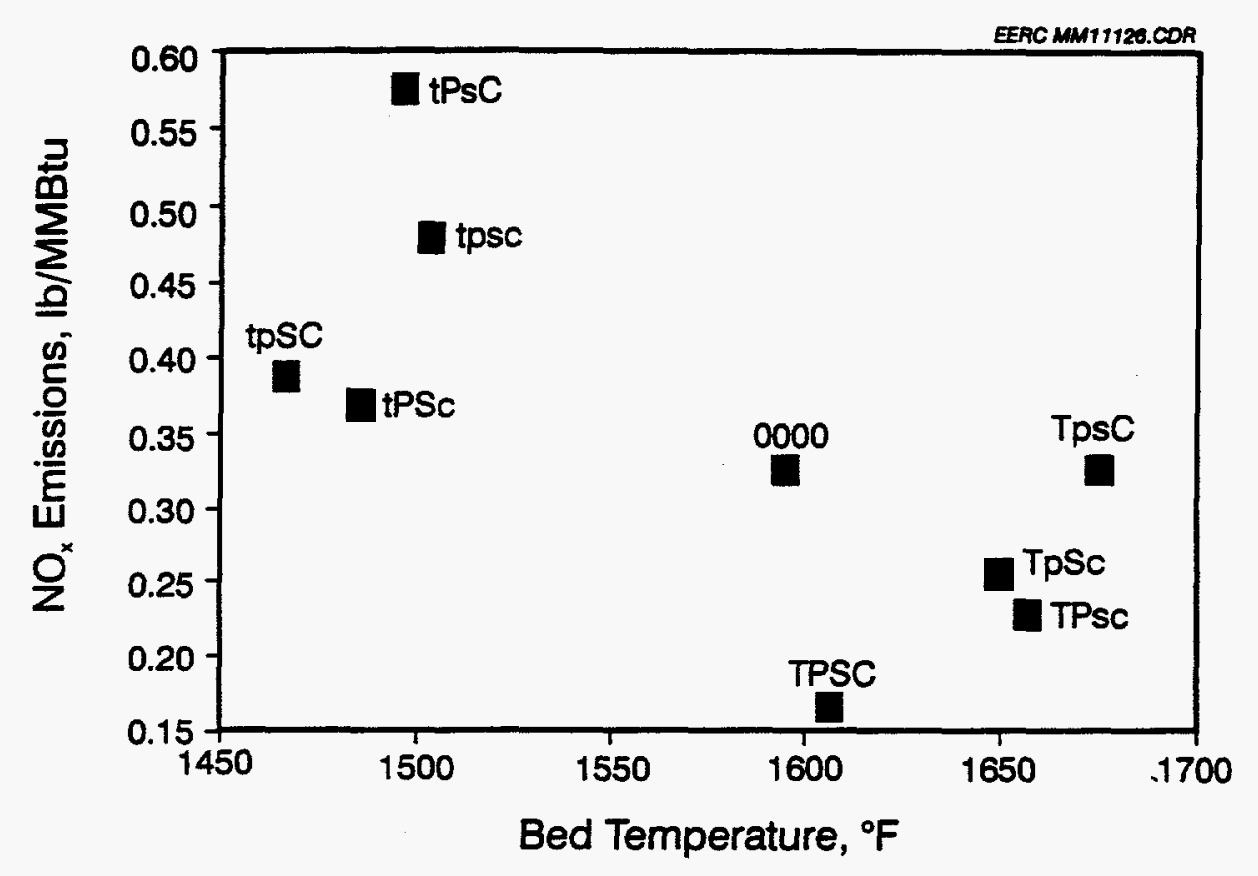

Figure 10. $\mathrm{NO}_{\mathrm{x}}$ emissions from the PFBR as a function of operating conditions.

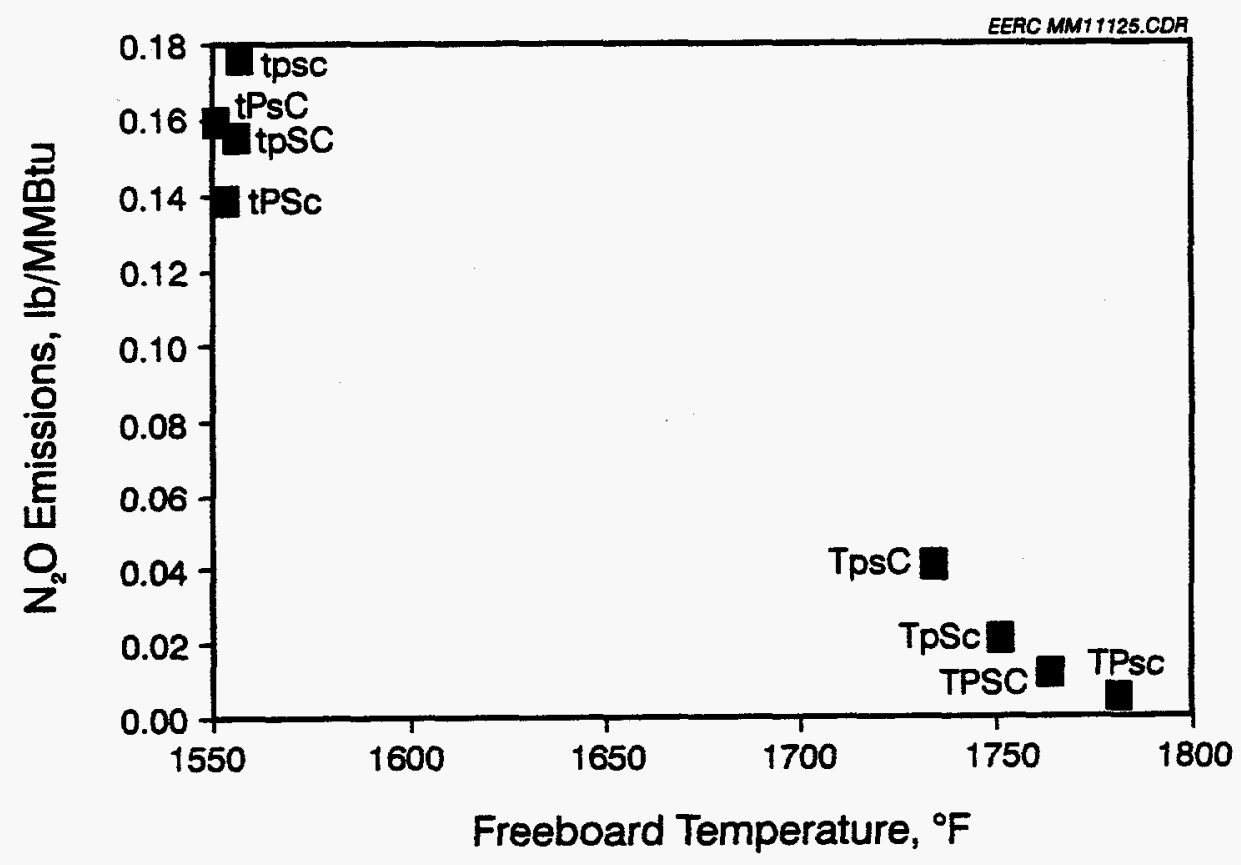

Figure 11. $\mathrm{N}_{2} \mathrm{O}$ emissions from the PFBR as a function of operating conditions. 


\section{TABLE 9}

Moisture, Proximate, Ultimate, Sulfur Forms, Heating Value, Ash Fusion, and Ash Analyses for Fuel Samples

\begin{tabular}{|c|c|c|c|}
\hline Analysis & RDF & Lignite & RDF-Lignite \\
\hline Solids Concentration, wt\% & 44.4 & 55.2 & 56.4 \\
\hline Viscosity, cP & 250 & 825 & 815 \\
\hline \multicolumn{4}{|l|}{ Proximate, $\mathrm{mf}^{1} \mathrm{wt} \%$} \\
\hline Volatile Matter & 56.1 & 42.7 & 49.2 \\
\hline Fixed Carbon & 32.8 & 47.0 & 40.9 \\
\hline Ash & 11.1 & 10.3 & 9.9 \\
\hline \multicolumn{4}{|l|}{ Ultimate, mf wt\% } \\
\hline Carbon & 68.0 & 66.0 & 67.4 \\
\hline Hydrogen & 7.2 & 4.6 & 5.8 \\
\hline Nitrogen & 0.5 & 0.9 & 0.8 \\
\hline Sulfur & 0.1 & 1.5 & 1.1 \\
\hline Oxygen & 13.1 & 16.7 & 15.0 \\
\hline \multicolumn{4}{|l|}{ Sulfur Forms, mf wt\% } \\
\hline Organic & 0.11 & 0.96 & 0.48 \\
\hline Pyrite & 0.01 & 0.33 & 0.57 \\
\hline Sulfatic & 0.01 & 0.02 & 0.04 \\
\hline \multicolumn{4}{|c|}{ Heating Value, Btu/lb, mf, wt\% } \\
\hline Experimental & 14,200 & 11,690 & 12,670 \\
\hline Calculated & 13,420 & 11,350 & 12,370 \\
\hline \multicolumn{4}{|c|}{ Ash Fusion, reducing atmosphere, ${ }^{\circ} \mathrm{C}$} \\
\hline Initial & 1366 & 1284 & 1220 \\
\hline Softening & $>1538$ & 1303 & 1261 \\
\hline Hemispherical & $>1538$ & 1309 & 1319 \\
\hline Fluid & $>1538$ & 1316 & 1423 \\
\hline \multicolumn{4}{|c|}{ Ash Component, $\mathrm{mf} w \mathrm{t} \%$ (as Oxides) } \\
\hline Silicon & 41.8 & 22.3 & 37.7 \\
\hline Aluminum & 36.0 & 10.7 & 24.7 \\
\hline Iron & 2.6 & 5.3 & 5.8 \\
\hline Titanium & 10.1 & 0.4 & 3.7 \\
\hline Phosphorous & 1.6 & 0.4 & 0.7 \\
\hline Calcium & 1.9 & 23.5 & 9.6 \\
\hline Magnesium & 2.3 & 11.2 & 6.6 \\
\hline Sodium & 0.4 & 0.9 & 0.7 \\
\hline Potassium & 0.3 & 0.3 & 0.4 \\
\hline Sulfur & 3.0 & 24.9 & 10.1 \\
\hline
\end{tabular}

'Moisture-free. 
TABLE 10

Average Operating Conditions from PFB Combustion Tests with Selected Fuels

\begin{tabular}{|c|c|c|c|}
\hline & Lignite Slurry & RDF Slurry & RDF-Lignite Blend \\
\hline Reactor Pressure, psig & 153.2 & 149.8 & 146.3 \\
\hline Slurry Feed Rate, lb/hr & 5.9 & 7.05 & 6.4 \\
\hline As-fired Slurry HHV, ' Btu/lb & 6466 & 6398 & 7143 \\
\hline As-fired Solids Loading, \% & 55.6 & 47.2 & 56.7 \\
\hline Slurry Heat Rate, Btu/hr & 38,150 & 45,110 & 45,720 \\
\hline Reactor FGV, ${ }^{2} \mathrm{ft} / \mathrm{s}$ & 2.94 & 3.11 & 3.09 \\
\hline Excess Air, \% & 23.3 & 22.2 & 25.9 \\
\hline Reactor $\mathrm{dP}$, in. $\mathrm{H}_{2} \mathrm{O}$ & 11.4 & 14.0 & 12.9 \\
\hline Avg. Zone 1 Temp., ${ }^{\circ} \mathrm{F}$ & 1509 & 1520 & 1507 \\
\hline Avg. Zone 2 Temp., ${ }^{\circ} \mathrm{F}$ & 1571 & 1603 & 1621 \\
\hline Avg. Zone 3 Temp., ${ }^{\circ} \mathrm{F}$ & 1586 & 1672 & 1767 \\
\hline Avg. Reactor Temp., ${ }^{\circ} \mathrm{F}$ & 1551 & 1580 & 1602 \\
\hline Carbon Burnout, \% & 98.5 & 99.0 & 99.5 \\
\hline \multicolumn{4}{|l|}{ Avg. Gas Emissions, as-run } \\
\hline $\mathrm{O}_{2}, \mathrm{~mol} \%$ & 4.5 & 4.4 & 4.9 \\
\hline $\mathrm{CO}_{2}, \mathrm{~mol} \%$ & 4.8 & 4.6 & 4.6 \\
\hline $\mathrm{CO}, \mathrm{ppm}$ & 0.5 & 3.2 & 3.2 \\
\hline $\mathrm{HC},{ }^{3} \mathrm{ppm}$ & 1.2 & 3.2 & 1.6 \\
\hline $\mathrm{SO}_{2}, \mathrm{ppm}$ & 137.9 & 18.0 & 39.2 \\
\hline $\mathrm{NO}_{x}, \mathrm{ppm}$ & 53.0 & 43.1 & 39.5 \\
\hline $\mathrm{N}_{2} \mathrm{O}, \mathrm{ppm}$ & 27.7 & 3.2 & 10.2 \\
\hline $\mathrm{Hcl}, \mathrm{ppm}$ & $\mathrm{ND}^{4}$ & 1.4 & 2.1 \\
\hline \multicolumn{4}{|c|}{ Avg. Gas Emissions, corrected to $3 \% \mathrm{O}_{2}$ without dilution $\mathrm{N}_{2}$} \\
\hline $\mathrm{CO}_{2}, \mathrm{~mol} \%$ & 14.0 & 12.4 & 13.1 \\
\hline $\mathrm{CO}, \mathrm{ppm}$ & 1.6 & 8.6 & 9.0 \\
\hline $\mathrm{HC}, \mathrm{ppm}$ & 3.6 & 8.8 & 4.4 \\
\hline $\mathrm{SO}_{2}, \mathrm{ppm}$ & 407 & 49.0 & 111 \\
\hline $\mathrm{No}_{x}, \mathrm{ppm}$ & 156 & 117 & 113 \\
\hline $\mathrm{N}_{2} \mathrm{O}, \mathrm{ppm}$ & 81.6 & 8.6 & 28.9 \\
\hline \multicolumn{4}{|l|}{ Avg. Gas Emissions, lb/MMBtu } \\
\hline $\mathrm{SO}_{2}$ & 0.62 & 0.10 & 0.22 \\
\hline $\mathrm{NO}_{\mathrm{x}}^{+}$ & 0.24 & 0.17 & 0.18 \\
\hline $\mathrm{CO}$ & 0.003 & 0.009 & 0.01 \\
\hline Avg. Sulfur Retention & 69 & 35 & 85 \\
\hline
\end{tabular}

High heating value.

${ }^{2}$ Flue gas velocity.

${ }^{3}$ Hydrocarbons.

${ }^{4}$ Not determined. 


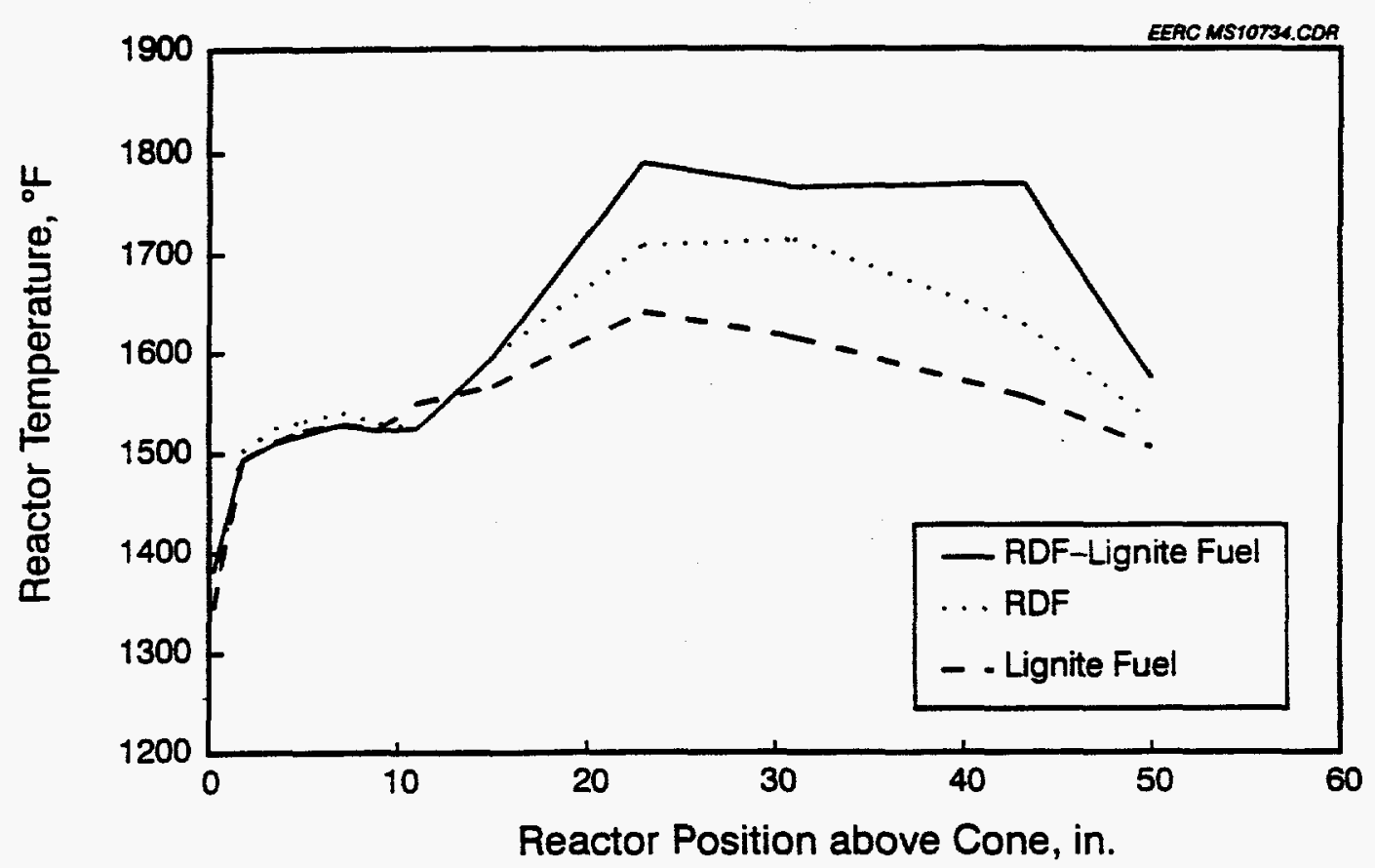

Figure 12. PFBR temperature distribution with various fuels.

The average gaseous emissions from these tests are also shown in Table 10. These emissions are shown on an as-run basis as well as corrected for dilution $\mathrm{N}_{2}$ and to $3 \% \mathrm{O}_{2}$. The emissions of components considered to be potential pollutants are also shown on a lb/MMBtu basis. The nitrogen oxide emissions from the RDF-based fuels were lower than those from the lignite fuel owing to the lower fuel-bound nitrogen for the RDF fuel. These levels are below the current federal standards for $\mathrm{NO}_{\mathrm{x}}$.

Carbon monoxide and hydrocarbon emissions appeared to be slightly higher for the fuels that contained RDF. These emissions were low and indicated a good burnout of the fuel. The hydrocarbon emissions detected from the volatile organic compounds (VOCs) analysis were not substantially different from those detected in the blank XAD-2 resin. Some of the compounds detected were naphthalene, diethyl benzenes, 1-methyl-1-propenyl benzene and C10-C12 branched hydrocarbons. These same compounds were detected in both the field and blank samples in approximately the same concentrations. Therefore, these compounds are believed to be coming from the XAD-2 resin and are not expected to be an emission problem for these fuels.

Table 11 shows the ash material balances for the three different tests. One result shown in Table 11 is that the fly ash passing through the cyclone decreased dramatically for the combustion test using the RDF-lignite blend. This lower fly ash level could be caused by the higher freeboard temperatures and/or interactions between the coal ash and the RDF ash, which would make the fly ash leaving the reactor more cohesive. The higher temperatures could increase the cohesivity (stickiness of the ash) making it easier to collect in the cyclone. Interactions between the RDF and 
lignite ash result in a larger ash particle size, as indicated by the mass median diameters of the cyclone fly ash presented in Tables 12,13 , and 14 . The larger, more sticky fly ash entering the hot primary cyclone is more efficiently collected.

TABLE 11

Ash Material Balance Through PFBR

\begin{tabular}{|c|c|c|c|c|c|c|}
\hline & \multicolumn{2}{|c|}{$\overline{\text { Lignite }}$} & \multicolumn{2}{|c|}{$\overline{\mathrm{RDF}}$} & \multicolumn{2}{|c|}{ RDF-Lignite } \\
\hline & Mass, $\mathrm{g}$ & wt $\%$ & Mass, $\mathrm{g}$ & wt\% & Mass, $\mathrm{g}$ & $w t \%$ \\
\hline \multicolumn{7}{|l|}{ Ash Material In } \\
\hline Bed Material & 1097 & 64 & 1400 & 81 & 1205 & 80 \\
\hline Fuel Ash & 616 & 36 & 324 & 19 & 299 & 20 \\
\hline Total Ash Material In & 1713 & 100 & 1724 & 100 & 1504 & 100 \\
\hline \multicolumn{7}{|l|}{ Ash Material Out } \\
\hline Spent Bed Material & 861 & 63 & 1098 & 67 & 1020 & 66 \\
\hline Cyclone Ash & 362 & 27 & 480 & 29 & 529 & 34 \\
\hline Fly Ash & 137 & 10 & 55 & 3 & 3.2 & $<0.2$ \\
\hline Total Ash Material Out & 1360 & 100 & 1633 & 100 & 1552 & 100 \\
\hline Closure, \% & \multicolumn{2}{|c|}{79} & \multicolumn{2}{|c|}{95} & \multicolumn{2}{|c|}{103} \\
\hline
\end{tabular}

TABLE 12

XRF and XRD' Analyses of PFBR Lignite Fuel Ash (high-temperature ash, \% of ash)

\begin{tabular}{|c|c|c|c|c|c|}
\hline \multicolumn{2}{|c|}{ Sample Number PFB-KR1-0694 } & Fuel Ash & Bed Material & Cyclone Ash & Fly Ash \\
\hline \multicolumn{2}{|l|}{ Loss on Ignition } & $\mathbf{N A}^{1}$ & 0 & 7.0 & 12.7 \\
\hline \multicolumn{2}{|l|}{ Particle Size, $\mu \mathrm{m}$} & NA & $\mathrm{ND}^{2}$ & 32.2 & 12.8 \\
\hline \multicolumn{6}{|l|}{ XRF Analysis } \\
\hline \multicolumn{2}{|l|}{$\mathrm{SiO}_{2}$} & 22.3 & 94.7 & 56.6 & 36.9 \\
\hline \multicolumn{2}{|l|}{$\mathrm{Al}_{2} \mathrm{O}_{3}$} & 10.7 & 1.2 & 6.9 & 13.1 \\
\hline \multicolumn{2}{|l|}{$\mathrm{Fe}_{2} \mathrm{O}_{3}$} & 5.3 & 0.6 & 4.5 & 6.0 \\
\hline \multicolumn{2}{|l|}{$\mathrm{TiO}_{2}$} & 0.4 & 0.0 & 0.4 & 0.5 \\
\hline \multicolumn{2}{|l|}{$\mathrm{P}_{2} \mathrm{O}_{5}$} & 0.4 & 0.1 & 0.3 & 0.2 \\
\hline \multicolumn{2}{|l|}{$\mathrm{CaO}$} & 23.5 & 1.7 & 15.4 & 23.6 \\
\hline \multicolumn{2}{|l|}{$\mathrm{MgO}$} & 11.2 & 0.6 & 5.3 & 8.3 \\
\hline \multicolumn{2}{|l|}{$\mathrm{Na}_{2} \mathrm{O}$} & 0.9 & 0.1 & 0.6 & 1.1 \\
\hline \multicolumn{2}{|l|}{$\mathrm{K}_{2} \mathrm{O}$} & 0.3 & 0.0 & 0.7 & 0.4 \\
\hline \multicolumn{2}{|l|}{$\mathrm{SO}_{3}$} & 24.9 & 1.0 & 9.3 & 9.8 \\
\hline \multicolumn{2}{|l|}{ Total } & 99.9 & 100.0 & 100.0 & 99.9 \\
\hline \multicolumn{6}{|c|}{ XRD Analysis of Cyclone Ash Material } \\
\hline \multicolumn{3}{|c|}{$\begin{array}{ll}\text { Major Phase: } & \text { Quartz } \mathrm{SiO}_{2} \\
\text { Minor Phase: } & \text { Anhydrite } \mathrm{CaSO}_{4} \\
& \text { Hematite } \mathrm{Fe}_{2} \mathrm{O}_{3}\end{array}$} & & & \\
\hline
\end{tabular}


TABLE 13

XRF and XRD Analyses of PFBR RDF Ash

(high-temperature ash, \% of ash)

\begin{tabular}{|c|c|c|c|c|}
\hline Sample Number PFB-RF1- 794 & Fuel Ash & Bed Material & Cyclone Ash & Fly Ash \\
\hline $\begin{array}{l}\text { Loss on Ignition } \\
\text { Particle Size, } \mu \mathrm{m}\end{array}$ & $\begin{array}{l}\text { NA }^{1} \\
\text { NA }\end{array}$ & $\begin{array}{c}0 \\
\mathrm{ND}^{2}\end{array}$ & $\begin{array}{l}3.75 \\
18.4\end{array}$ & $\begin{array}{l}2.50 \\
5.7\end{array}$ \\
\hline \multicolumn{5}{|l|}{ XRF Analysis } \\
\hline $\begin{array}{l}\mathrm{SiO}_{2} \\
\mathrm{Al}_{2} \mathrm{O}_{3} \\
\mathrm{Fe}_{2} \mathrm{O}_{3} \\
\mathrm{TiO}_{2} \\
\mathrm{P}_{2} \mathrm{O}_{5} \\
\mathrm{CaO} \\
\mathrm{MgO} \\
\mathrm{Na}_{2} \mathrm{O} \\
\mathrm{K}_{2} \mathrm{O} \\
\mathrm{SO}_{3} \\
\text { Total }\end{array}$ & $\begin{array}{r}41.8 \\
36.0 \\
2.6 \\
10.1 \\
1.6 \\
1.9 \\
2.3 \\
0.4 \\
0.3 \\
3.0 \\
100.0\end{array}$ & $\begin{array}{r}95.7 \\
2.5 \\
0.2 \\
0.3 \\
0.0 \\
0.6 \\
0.4 \\
0.0 \\
0.0 \\
0.1 \\
99.8\end{array}$ & $\begin{array}{r}49.5 \\
23.6 \\
3.5 \\
3.0 \\
0.7 \\
7.6 \\
4.1 \\
1.2 \\
0.7 \\
6.0 \\
99.9\end{array}$ & $\begin{array}{r}47.3 \\
38.5 \\
2.0 \\
5.3 \\
1.3 \\
1.7 \\
2.2 \\
0.3 \\
0.4 \\
0.9 \\
99.9\end{array}$ \\
\hline \multicolumn{5}{|c|}{$\begin{array}{c}\text { XRD Analysis of Cyclone Ash Material } \\
\text { Major Phase: } \\
\text { Minor Phase: } \\
\text { Anhydz } \mathrm{SiO}_{2} \\
\\
\text { Hematite } \mathrm{Fe}_{2} \mathrm{O}_{3}\end{array}$} \\
\hline
\end{tabular}

1 Not applicable.

2 Not determined.

TABLE 14

XRF and XRD Analyses of PFBR RDF-Lignite Fuel Ash (high-temperature ash, \% of ash)

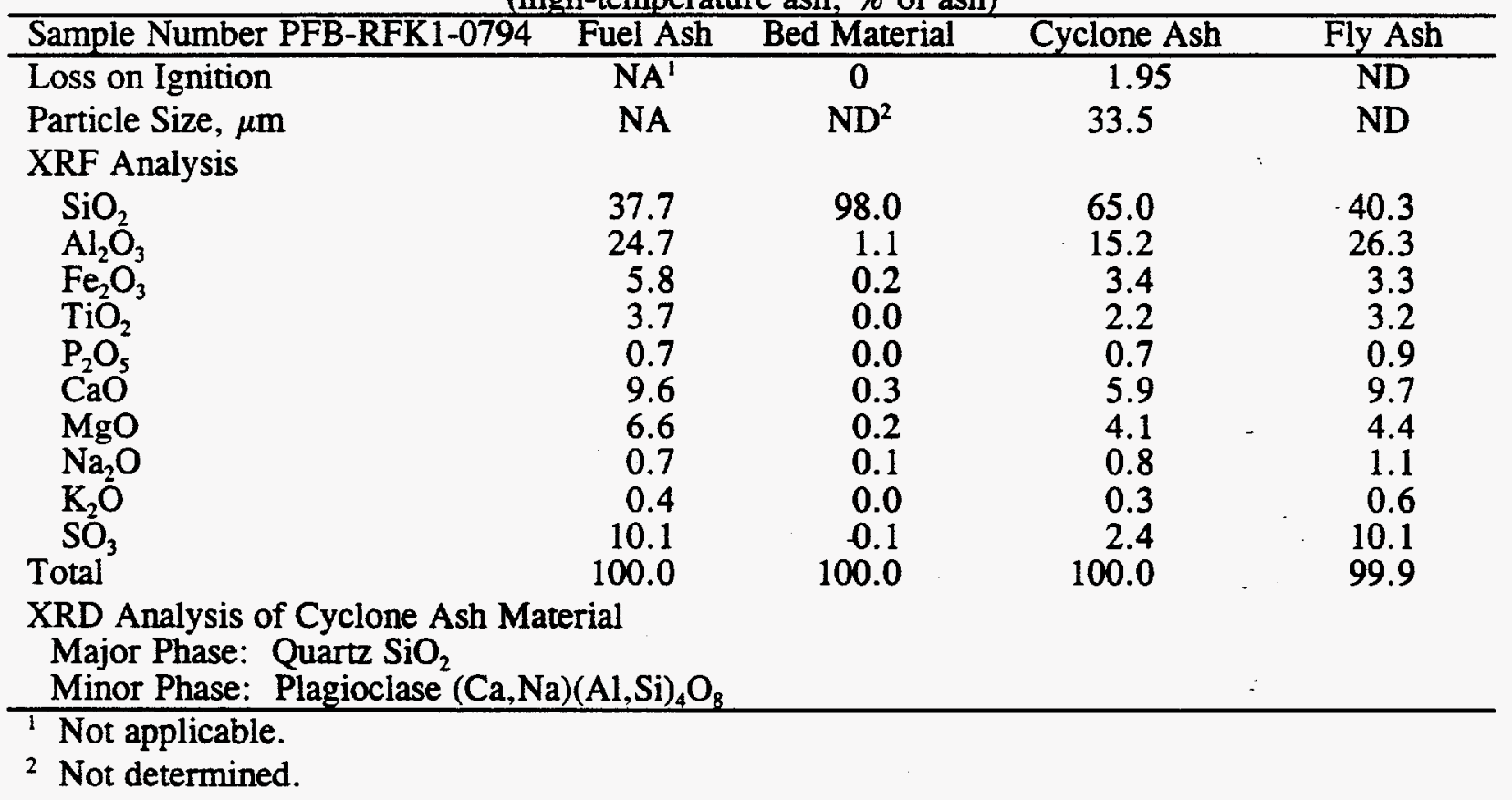


These data indicate that the $\mathrm{SO}_{2}$ emissions decrease significantly when the $\mathrm{RDF}$ and RDF-lignite blend are used. This result was expected because of the low sulfur levels in the RDF. The low $\mathrm{SO}_{2}$ numbers were also the result of the relatively high sulfur retention performance of these fuels, retaining the sulfur in the ash material. Figure 13 compares the $\mathrm{SO}_{2}$ emissions and sulfur retention for each fuel. Tables 12,13 , and 14 show the results of XRF and XRD analyses of the fuel ash as compared to composite bed material, cyclone ash, and fly ash samples. With all three fuels, the bed material was composed mostly of the silica sand bed material, with very little calcium and sulfur being retained. The cyclone ashes from these fuels tended to contain more of the calcium, magnesium, and sulfur than did the other fractions. While the cyclone ash from the RDF combustion did not contain very much calcium and magnesium, the relatively high $\mathrm{SO}_{3}$ concentration indicates that the available calcium and magnesium were highly sulfated. The intermediate concentration of calcium and magnesium in the RDF-lignite blend, together with the low $\mathrm{SO}_{3}$ concentration, indicates the presence of excess calcium in the RDF-lignite blend and is consistent with the high sulfur retention seen with this fuel.

Results from toxicity characteristic leaching procedure (TCLP) tests are shown in Table 15 for both the bed material and the cyclone ash for each of the fuels tested. The TCLP is designed to determine the mobility of both organic and inorganic components of solid or liquid wastes out of the waste and into the environment. In this case, the solid residues from these combustion tests were extracted with 20 times the weight of the solid in the appropriate extraction fluid. The choice of extraction fluid depends on the alkalinity of the solid phase. Following extraction, the fluid is separated from the solid phase and analyzed by atomic absorption (AA) or inductively coupled atomic plasma (ICAP). The only Resource Conservation and Recovery Act (RCRA) metal that appears to present a possible problem for the disposal of these combustion by-products in a landfill is leachable chromium. The cyclone ash samples seem to contain significantly more chromium than the spent bed material. Approximately $43 \%$ of the chromium content in various household waste fractions (i.e., sources of RDF) can be attributed to metal alloys (1). These metal alloys could be reduced by a more discriminating resource recovery process rather than the "handpicked" RDF process from which the current fuel source was supplied.

\subsection{SUMMARY}

The EERC has recently commissioned a 3-in.-ID pressurized fluidized-bed reactor to be used for sorbent characterization, the evaluation of gaseous emission including testing for trace elements, and agglomeration and hot-gas cleanup testing. Initial results from the characterization of alkali gettering indicate that in-bed getters can remove a significant amount of the alkali in the bed. Using kaolin as a sorbent, sodium levels in the flue gas were reduced from $3.6 \mathrm{ppm}$ to less than $0.22 \mathrm{ppm}$. Sulfur was also reduced by $60 \%$ using the kaolin sorbent. Future work will examine the impact of operating conditions and sorbent type and size on the reduction of alkali.

Other testing focused on the characterization of sulfur sorbents. The intent of the study was to develop a reliable technique to predict the performance of sorbents in the PFBC. One limestone has been characterized to date, with testing on additional sorbents planned. Preliminary: resultsindicate that although the total sulfur capture is significantly lower than that observed in a full-scale PFBC, the emission trends tend to be similar. The true test of the small PFBR will come when additional 


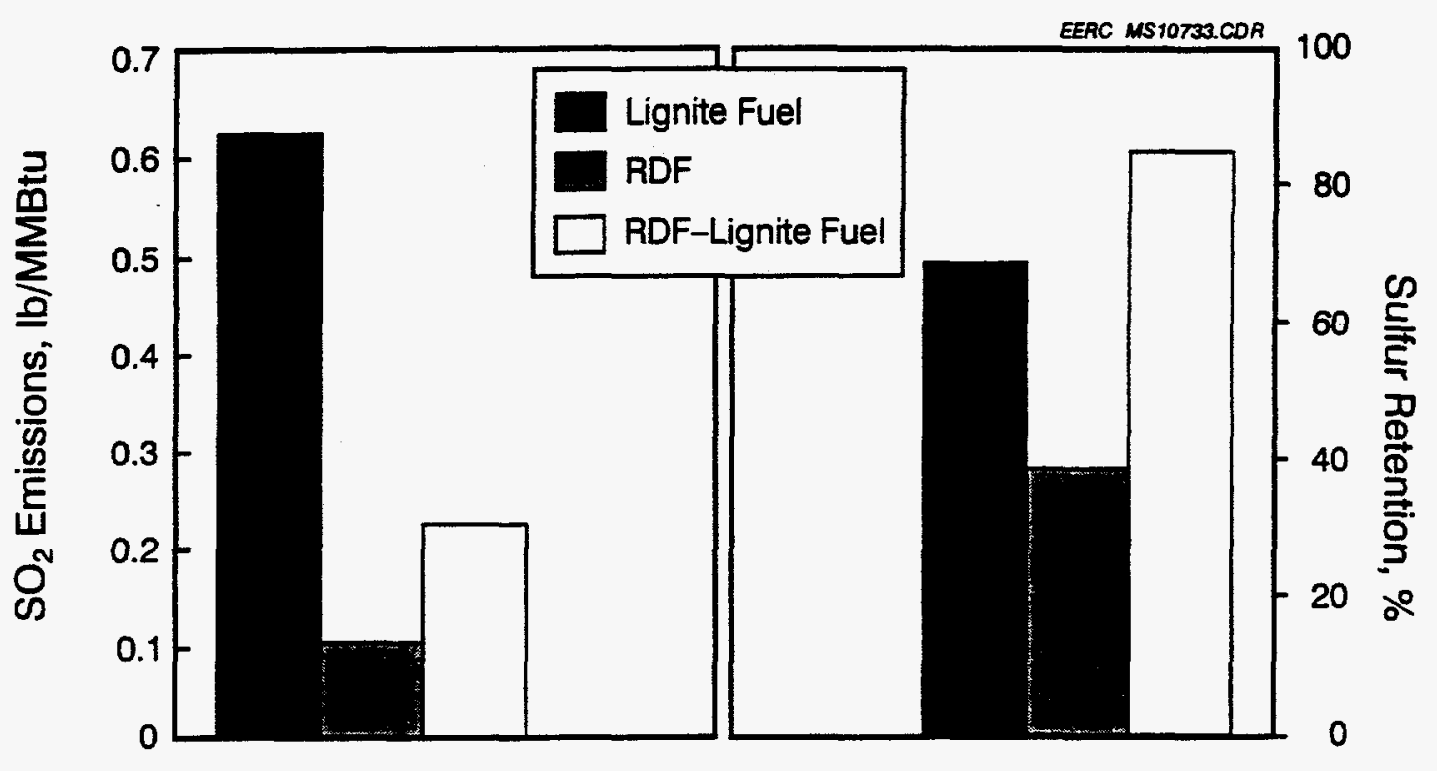

Fuel Type

Figure 13. Comparison of $\mathrm{SO}_{2}$ emission and sulfur retention for each fuel type.

sorbents are tested, the relative trends are ranked against other sorbents, and the data of the small PFBR are compared to full-scale data. Additional data is being generated and can be obtained from the authors.

The RDF and RDF-lignite fuels combusted very well in the PFBR combustion facility at the EERC, with combustion efficiencies exceeding $99.0 \%$ in all cases. Sulfur dioxide emission was significantly lower for the RDF-based fuels than the levels seen for the lignite fuel alone. The nitrogen oxide emission was lower for the RDF-based fuels than that experienced from the lignite fuel owing to the lower fuel-bound nitrogen for the RDF fuel. Sulfur dioxide and nitrogen oxide emissions were well below current federal regulations. Carbon monoxide and hydrocarbon emissions appeared to be slightly higher for the fuels containing RDF but were below $9 \mathrm{ppm}$ for the worst case (RDF alone). Analysis of VOC emission does not indicate an emission problem for these fuels. Some differences were apparent in the amount of particulate matter exiting the primary cyclone between the RDF-lignite blend and both the lignite fuel and the RDF slurry alone. Chromium appears to be the only RCRA metal that might present some disposal problem; however, processing of the RDF with the wet resource recovery method should reduce the levels of chromium to below those seen in the current test fuel. 
TABLE 15

Results from TCLP Tests for RCRA Metals on Selected

Combustion Products Derived from All Three Slurry Fuels

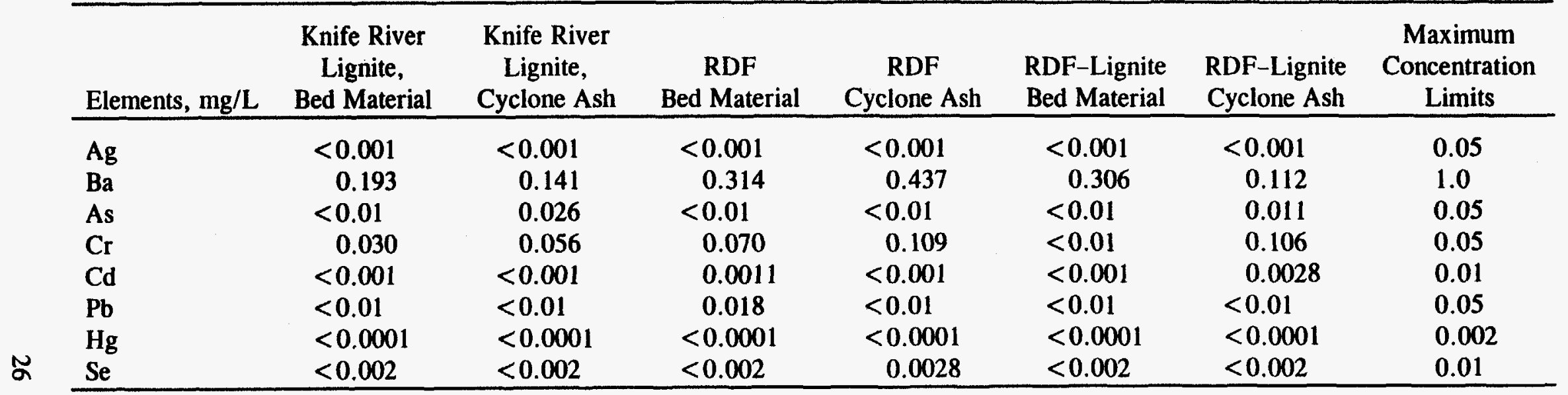




\subsection{REFERENCES}

1. Newby, R.A.; Keairns, D.L.; Lippert, T.E.; Alvin, M.A.; Bachovchin, D.M. "PFBC at Higher Combustion Temperatures," Modern Power Systems 1989, 9 (11), 41-47.

2. Collings, M.E.; Mann, M.D. "Empirical Modeling of $\mathrm{N}_{2} \mathrm{O}$ Emissions from Circulating Fluidized-Bed Combustion," Energy \& Fuels 1994, 8, 1083-1094. 